\title{
Literature Relating to the Recorder
}

\section{Christopher Welch OXON M.A.}

To cite this article: Christopher Welch OXON M.A. (1897) Literature Relating to the Recorder, Proceedings of the Musical Association, 24:1, 145-224

To link to this article: http://dx.doi.org/10.1093/jrma/24.1.145

\section{曲 Published online: 28 Jan 2009.}

Submit your article to this journal $₫$

Џ Article views: 9

Q View related articles $₫$ 
JUNE 14, 1898.

W. H. CUMMINGS, Es\&.,

IN The Chair.

\section{LITERATURE RELATING TO THE RECORDER.}

By Christopher Welch, M.A., Oxon.

What was a recorder? How many different answers have been given to this question.

An Englishman in search of a reply would turn, as a matter of course, first of all to Johnson's Dictionary, where he would find that the cautious lexicographer, keeping on safe ground, pronounces a recorder to be "a kind of flute." But if the inquirer, desirous of testing the correctness of the Doctor's statement by the light of a more modern authority, were to consult Webster, he would be told that a recorder was " a kind of flageolet," for which, in a later edition, there is substituted another explanation: " an instrument resembling the flageolet." Should this be deemed unsatisfactory, and recourse he had to the "Century Dictionary" (188g) for the latest declaration on the subject, a description of the instrument would come to light, but a description which adds at least one other to the statement in Webster which will not bear examination. A recorder is said to be "a musical instrument of the flageolet family, having a long tube with seven holes and a mouth-piece. In some cases an eighth, covered with gold beaters' skin, appears near the mouth-piece, apparently to influence the quality of the tone."

The recorder is mentioned in some of the most important works in the English language. Those who have edited such works have naturally been desirous of giving their readers an idea of the instrument. What confusion and uncertainty we find in their accounts of its peculiarities! For instance, on the 8th of April, 1668, Mr. Samuel Pepys paid a visit to his flute maker, Drumbleby, " and did talk," he says, "a great deal about pipes; and did buy a recorder, which I do intend to learn to play on, the sound of it being, of all sounds in the world, most pleasing to me." Now in Bright's " Pepys" (1875) we are informed that "a recorder was a large flute blown 
through a mouth-piece, like a clarionet in the present day "; but in the still more elaborate edition of the Diary which has lately been brought out by Mr. Wheatley, a recorder is stated to be " a reed instrument, but in the side near the mouth-piece there was a hole covered with a piece of bladder, which modified the quality of the sound."

Again, when Queen Elizabeth visited Kenilworth, in 1575, there awaited her a magnificent reception. Even gods and goddesses vied with each other in hailing her with tokens of joy. A chronicler, who goes into minute details of the preparations which were made for the occasion, states that there were erected at the sides of the road by which she would pass, as she approached the castle, seven pairs of posts. On the first pair were "too cumly square wyre cagez" containing birds, as gifts to her Majesty from Sylvanus the god of "Foul"; on the second, "too great sylver'd bollz" filled with fruit, as gifts from Pomona, the goddess of "Frutez"; on the third pair, two similar bowls in which was corn as the gift of Ceres. On the fourth, fifth, and sixth pairs were displayed grapes and wine, fish, and arms and armour, as offerings from Bacchus, Neptune, and Mars respectively. "On the seaventh posts, the last and next too the Castl," the chronicler states, "wear thear pight [i.e., placed] too saer Bay braunchez of a four foot hy, adourned on all sides with lutes, viollz, shallmz, cornets, flutes, recorders, and harpes, az prezents of Phobus, the god of Muzik for rejoycing the mind, and of phizik for health to the body."

I ought not to omit to add that musical instruments were not merely displayed in dumb show; there was in store for the royal guest a "delicate harmony" of a kind of which I shall have more to say-a concert of flutes. "At the eend of the Bridge," continues the chronicler, "and entree of the gate, waz her Highnes received with a fresh delicate armony of flutz in perfourmauns of Phoebus prezents." She had previously been greeted with " a delectable harmony of hautboiz, shalmz, cornets and such other looud muzik" after having been saluted by trumpeters with "a tune of welcum : which, besyde the nobl noyz, was so mooch the more pleazaunt too behold, becauz theez trumpetoourz, being sixe in number, wear every one an eight foot hye, in due proportion of parson besyde, all in long garments of sylk suitabl, each with his silvery trumpet of a five foot long, formed taper wyse, and straight from the upper part untoo the neather eend, whear the diameter was a 16 inches over, and yet so tempered by art, that being very eazy too the blast, they cast foorth no greater noyz, nor a more unpleazaunt soound for time and tune, than any oother common trumpet, bee it never so artificially formed." 
The note which Mr. Nichols, in his " Progresses of Queen Elizabeth," 1 appends to this passage, gives a good idea of the straits to which commentators were reduced in their efforts to explain the nature of the recorder. He has recourse to his imagination, and proceeds to construct a recorder out of the allusions made to the instrument by Lord Bacon. He does not even know what the fipple was. Nor is this to be wondered at ; for, even at the present day, there is no dictionary or encylopædia with which I am acquainted in which an adequate explanation of the fipple of a flute is offered." He states that Bacon used the word' to denote the mouth-piece of the instrument; but when I quote Bacon's words, as I shall have occasion to do, it will be seen that this was only a bad guess. For enlightenment he has gone, as might be expected, to Johnson's Dictionary, where he has been informed that a fipple is " a stopper," and that the word is derived from the Latin fibula Although fibula signifies a clasp, not a stopper, so great is the weight of Johnson's name that this derivation still passes from dictionary to dictionary. Mr. Nichols, then, informs his readers that recorders " were wind instruments somewhat resembling flutes, or rather clarionets; for by the description which is

1 Vol. I., p 433.

Since the above was written, the letter $F$ has been reached in Dr. Murray's Dictionary, now in course of publication. Here an advance has been made, a fipple being stated to be " the plug at the mouth of a wind instrument by which the volume was contracted." Fipple had previously been connected with wind instruments both in the Imperial and in the Century Dictionary, but only in the following vague and unsatisfactory explanation: "a stopper, as at the mouth of a musical wind instrument."

- No other derivation of fipple than that from fibula has, as far as I am aware, hitherto been proposed.

In Scotch the word fipple signifies "the under lip in men or animals" (Jamieson's Dic., s.v., "Faiple"), It is possible that a resemblance may be traced between the section of the fipple, as it appears at the beak of a flute, and an underlip; but I will suggest for the consideration of etymologists that the word may, perhaps, be traced to "pipe" in the following way. In Somersetshire, when a boy plucks a dandelion, and, pinching the stalk so as to form a reed, proceeds to elicit from it a squeaking sound, he terms the instrument thus constructed a fib-that is, clearly, a pib, or pipe (confer " pibcorn," infra, p. 158, note 37). When he makes (or did make, for the art is becoming extinct) the spirally wound willow bark trumpet, known in Oxfordshire as a Whit-horn (see a paper on "A Primitive Musical Instrument," by $H$. Balfour, in "The Reliquary and Illustrated Archxologist," October, 1896), but which he calls a May horn, he names the reed by which it is sounded, whether it be made of dandelion or willow bark, the fib. Again, if he takes a twig of willow, notches it so as to form the finger-holes and the mouth of a fipple flute, cuts it slantwise at one end for the beak, then, after detaching the bark, which becomes a tube, constructs a fipple out of the piece of wood above the mouth by removing a slice to form the flue, he designates the fipple, which, like the reed of the May horn, makes the tube yield sound, the fib of the instrument. Thus we have. $f p p l e, f i b$, pib, pipe. 
given of one by Lord Bacon, in the second century of his 'Sylva Sylvarum,' at the 159th and 16oth experiments, it may be ascertained that the instrument was blown at one end. It appears from the same authority that it consisted of a tube with stops or wind holes, and a fipple, or mouthpiece; the lower end open, like flageolets of the present time. The word 'fipple,' used by Bacon for mouth-piece, signifies literally a stopper, from the Latin fibuli," whence it may be argued that the upper end of the recorder terminated in a cap, from whence issued the pipe that conveyed the breath throughout the whole instrument."

It is not, however, until we look into Shakespeare that we realise the density of the clouds which envelope the recorder and become fully alive to the need there is of dispelling the darkness in which the instrument is enshrouded. On none of the plays of the great dramatist has so much been written as on "Hamlet"; of all the scenes in that much-debated tragedy few have attracted more attention or given commentators more trouble than the recorder scene. In the collection of the plays published by Shakespeare's friends, John Heminge and Henry Condell, so well known as the folio of 1623 , the passage "govern these ventages with your fingers and thumb," appears as "govern these ventiges with your finger and thumb." Which is right-fingers and thumb, or finger and thumb? Were there several holes for the fingers on the recorder, as on the flute, or was the instrument constructed with two holes only, a hole for a finger and a hole for a thumb, having thus one hole less than the pipe played with the tabour, which has three holes-two for the fingers and one for the thumb? So vague was the information at the command of commentators that they have never settled the matter, there being modern editions of Shakespeare, including that of Mr. Dyce, who has taken great pains with the text, in which we still read "finger and thumb."

But a more knotty question awaited the commentators. "Hamlet" was first published separate from the other plays: it appeared in a series of editions of a quarto size. The first quarto, which came out in 1603 , is a bastard version of the tragedy; it is generally regarded as a surreptitious issue, based either on recollection or else on notes taken during the representation; some, however, are of opinion that it is an early sketch by Shakespeare himself, and that it thus represents his first conception of the work. It was followed in the next year, 1604, by a second quarto "according to the true and perfect coppie" of the play. In the spurious edition, the quarto of 1603 , there is no mention of the fingers and thumb, the passage reading "'Tis but stopping of these holes"; but in the quarto of 1604 , the first

- Obviously a misprint of fibula. 
edition of the true copy, we read govern these ventages, not with your fingers and thumb, but with your fingers and "the umber." There was, then, no hole on the recorder for the thumb, the ventages being closed by the fingers with the assistance of the umber. What was the umber? Here was a problem I In the absence of fact to fall back upon, fancy was ready with an answer : the umber, she whispered, was a key, whereupon the commentators proceeded to exercise their acumen and to display their learning as follows :-

"The umber," says Mr. Steevens, "may probably be the ancient name for that piece of moveable brass at the end of a flute which is either raised or depressed with the finger. The word umber is used by Stowe, the chronicler, who, describing a single combat between two knights, says: 'He brast up his umber three times.' Here the umber means the visor of the helmet. So, in Spencer's 'Fairy Queene,' book III., c. i., st. 42 :-

- But the brave maid would not disarmed be, But only vented up her umbriere, And so did let her goodly visage to appere.'

Again, book IV., c. iv. :-

'And therewith smote him on his umbriere.'

Again, in the second book of Lidgate on the Trojan War, 1513 :-

'Through the umber into Troylus' face." "

Tollet, another well-known commentator, writes thus : "If a recorder had a brass key like the German flute, we are to follow the reading of the quarto; for then the thumb is not concerned in the government of the ventages or stops. If a recorder was like a tabourer's pipe, which has no brass key, but has a stop for the thumb, we are to read, 'Govern these ventages with your finger and thumb.' In Cotgrave's Dictionary, ombre, ombraire, ombriere, and ombrelle are all from the Latin umbra and signify a shadow, an umbrella, anything that shades or hides the face of the sun; and hence they have been applied to anything that hides or covers another; as, for example, they may have been applied to the brass key that covers the hole in the German flute." "s

I feel tempted to give other instances; but, not to be wearisome, I will stop here, only adding that, of all the accounts I have read, there is one only the writer of which

s "The umber" is, begond all doubt, nothing but a misprint of "thumbe," an " $e$ " having been introduced after the "th," and an " $r$ " added at the end of the word. In the quarto of I6rr. "the umber" is cerrected into "the thumb." In the first, second, and thind folios we find " and thumbe." 
had a clear and correct idea of what a recorder was, that being in a note by Mr. Way in his commentary on the Promptuarium Parvulorum, in the edition of that work published by the Camden Society. In complying with the request, with which I have been honoured, to read a paper before the Musical Association, it is my purpose to show how pardonable are these wanderings, inasmuch as the chief authorities on musical matters, to whom laymen would naturally turn for guidance, have themselves gone hopelessly astray. After classifying flutes in a manner suitable for my purpose, I shall quote passages from old writers in which the recorder is mentioned, then give a brief historical sketch of the instrument, and afterwards proceed to point out, and trace to their source, the errors into which the historians of music, Sir John Hawkins, Dr. Burney, and Mr. William Chappell, have fallen.

"Flute" was formerly, like the Greek "aìdos" and the English " pipe," a generic term. It was applicable to most, if not to all of the members of the wood-wind, including those blown with a reed; a sense in which we still use it when we speak of the May flute, the Straw flute, the Eunuch flute, or the flutes of the ahcients. In the present day, however, the word is usually restricted to instruments the sound of which is produced by the impact of a jet of air on a cutting edge.

I shall divide flutes, thus defined, into three classes, basing my classification on the way in which the flue, throat, or fissure, from which the jet issues, is formed.

In the first, it is formed by the nostril of the performer; in the second, by the muscular action of the lips; in the third, by inserting into the instrument itself a plug, or plate, which partially blocks, and so narrows, the tube.

I shall call members of the first class nostril flutes; of the second, lip flutes; of the third, fipple fiutes, fipple being the technical name of the plug by which the tube is reduced in size.

The nostril or nose flute does not come within the scope of our inquiry. It is in use chiefly, but not exclusively, in the islands of the Pacific Ocean; in Europe it is only to be found in museums and in the cabinets of collectors. ${ }^{\circ}$

With the lip or mouth flute we are all familiar, for a member of the family, the transverse or German flute, with

- The nose flu e is described in Ellis's "Polynesian Researches," ch. viii.; in "Hawkesworth's Voyages," Vol. II., p. 205: in a paper entitled " Notes on the Asiatic Relations of Polynesian Culture," published in the journal of the Anthropological Institnte, May, I882, and in M. Victor Mahillon's "Catalogue du Musée Instrumental du Conservatoire de Musique de Bruxelles," second edition, pp. 176, 408. A general acconnt of the instrument is given in the writer's "History of the Boehm Flute," third edition, pp. 257 to 67. 
its diminutives the piccolo and the fife, is in dally use amongst us. To this class belongs the Pan flute, as well as the Egyptian nay.

The fipple flute, with which this paper will chiefly deal, is now well nigh extinct; not that the construction of sound producers on its principle has ceased; far from it, they are made in thousands, from the Liliputian whistle an inch long up to its Brobdignagian descendant, the organ-pipe, thirtytwo feet high. But, if we except the so-called flageolets which decorate our shop windows, as a finger-holed instrument in actual use, the fipple flute only survives in the little six-holed pipe so often heard in the streets of,London, which, though known in this country by the contemptuous appellation of the penny whistle, still bears in France the name which our Gallic neighbours formerly assigned to its once popular predecessor, "The English Flute."

Having now explained the meaning $I$ attach to the expressions lip flute and fipple flute, terms which I shall often use in this paper, I will proceed to cite passages from old writers in which mention is made of the recorder.

I have already given a quotation, it will be remembered, in which the recorder and the flute are named together; the presents offered by Phobus to Queen Elizabeth as she approached Kenilworth, in 1575, comprised both recorders and flutes.7 Coming half-a-century or so nearer to our time, we find the recorder associated, not only with the flute, but with the fife; in Drayton's "Polyolbion" (1613-22), amongst the instruments played by the English in their musical contest with the Welsh are recorders, flutes, and fifes; whilst the tabourer's pipe, an instrument of the fipple flute family, is atso included :-

So were there some again, in this their learned strife,

Loud instruments that loved, the cornet and the fife,

The Hoboy, sagbut deep, recorder and the flute:

Even from the shrillest shawm unto the cornamute.

Some blow the bagpipe up, that plays the country round,

The Taber and the Pipe some take delight to sound.

Running back rather more than a century, we come to Hawes's "Passetyme of Pleasure," a "boke" made in the twenty-first year of the reign of Henry VII. $(1506) .^{g}$ In this

I Supra, p. 146.

Stephen Hawes studied at Oxford, then travelled on the Continent, and afterwards became groom of the chamber of Henry VII. On the Queen's death, in 1502, he received four yards of black cloth for mourning, but he does not appear to have received any cloth when the King died, in I509, from which it is inferred that he no longer held the appointment. "The Pastime of Pleasure" has been reprinted by the Percy Society (Vol. XVIII.). The passage quoted above occurs in the sixteenth chapter of the poem. 
poem we find an allusion to the characteristic for which the recorder was so celebrated, its sweetness.

There sat dame Musyke with all her mynstracy;

As tabours, trumpettes, with pipes melodious,

Sakbuttes, organs, and the recorder swetely,

Harpes, lutes, and crouddes ryght delycyous ;

Cymphans, doussemers, wyth clavicimbales glorious,

Rebeckes, clavycordes, eche in theyr degre,

Did sytte aboute theyr ladyes mageste.

Possibly of about the same period as "The Pastime of Pleasure" is a passage with which, as it has been so often repeated, most of those present are doubtless familiar. I allude to the lines on the recorder from the "Proverbis in the garet at the New lodge in the parke of lekingfelde," quoted by Mr. William Chappell in his " Popular Music of the Olden Time." These so-called proverbs are said to have been written on the walls of an upper room in the Manor House of Leckingfield (a Yorkshire residence which belonged to the Percy family) in the reign of Henry VII. And here I must commence my ungracious task of pointing out mistakes. It will be recollected that the second line of the proverb devoted to the recorder is stated to run thus: "Manifold fingering and stops bringeth high notes from its clear tones." Mr. Chappell placed the word " notes " in a parenthesis," it having been interpolated to make sense, "bringeth high from its tones" being unintelligible. The line so printed has passed into other books, until, as in Grove's Dictionary, the parenthesis has been dropped, so that the reader is not aware that the word "notes" did not originally form part of the text. Now, on looking into the manuscript ${ }^{10}$ from which the proverbs are taken, we find neither "high," "notes," nor "tones," the line having been misinterpreted in the following way:-

The word "high " was formerly often spelt " hy." It is so spelt in a proverb preceding that which we are considering :-

A Shawme makithe a sweete sounde for he tunithe Basse,

It mountithe not to $h y$, but kepithe rule and space."

But, on looking at the "hy" in the proverb relating to the recorder, we see a line drawn horizontally over the " $y$. "

- See infra, p. 216.

10 Royal MS. x8, D. II., British Musenm.

1 The two remaining lines of this proverb are of interest, inasmuch as they seem to contain an allusion to the tendency of the shawm to fly into the twelfth above the note fingered, a peculiarity of which Denner availed himself in the construction of the clarinet:-

"Yet yf it be blowne with a too vehement wynde, It makithe it to misgoverne out his kynde." 
This is an indication that the letter " $\mathrm{m}$ " is omitted, " hy" so written being an abbreviation, a common one, of the word " him," which was once spelt " hym "; the whole proverb reading thus:-

"The recorder of his kynde the meane dothe desyre,

Manyfolde fyngerynge and stoppes bryngithe hy from" [him from-i.e., from him] " his tunes clere.

Who so lyst to handill an instrument so goode

Must se in his many fingeryne $y^{*}$ he kepe tyme, stop and moode."

We will now pass to an earlier enumeration of musical instruments, that found in the "Squyr of Lowe Degre." 19 The date of this romance, like that of the proverbs at Leck. ingfield, is conjectural ; but 1475 , ten years before the accession of Henry VII., has been named as probable :-

There was myrth and melody

With harp, getron and sautry,

With rote, ribible and clokarde,

With pypes, organs and bumbarde,

With other mynstrelles them amonge,

With sytolphe and with sautry songe,

With fydle, recorde, and dowcemere,

With trompette and with claryon clere,

With dulcet pipes of many cordes.

I must not omit to notice that " recorder " occurs in a work where its presence is an indication that the word was not confined to England in the fifteenth century, but was known also in Scotland; in the "Buke of the Howlate, maid be Holland," not only is " recorder" to be found, but, possibly, though this is very doubtful, "fife." Mention is also made of a wind instrument very rarely named, the lilt-pipe. Good reasons have been adduced for the belief that "The Houlate" was written not far from I450, so that it is about a quarter of a century earlier than "The Squire of Low Degree."'s

\section{n Ritson's "Metrical Romances."}

28 "The Houlate" (Anglice, the Owl) was first printed in Pinkerton's Scottish Poems (Vol. LII., p. 179), afterwards by Lang, and again by the Hunterian Club. In 1893 an edition of the text ("Holland's Buke of the Houlate," by Arthur Diebler) was published at Leipsic, in which two MSS., one written in the early part of the sixteenth century by John Asloan, the other in 1568 by George Bannatyne, were carefnlly collated. Certain differences noted by Diebler are given below. 
All thus our ladye they lofe, with liking and list, Menstralis and musicians mo than I mene ${ }^{25}$ may,

The psaltery, the citholis, ${ }^{10}$ the soft cytharist, ${ }^{17}$

The croude, and the monycordis, the gythornis ${ }^{20}$ gay,

The rote, and the recordour, the ribup, ${ }^{10}$ the rist, ${ }^{\infty}$

The trump, and the taburn, the tympane but tray;

The lilt pype and the lute, the cithill ${ }^{\infty}$ in fist,

The dulsate, ${ }^{23}$ and the dulsacordis, the schalm ${ }^{*}$ of assay ;

The amyable organis usit full oft,

Clarions ${ }^{20}$ loude knellis,

Portativis and bellis,

Cymbaclanis ${ }^{n}$ in the cellis

That soundis so soft.

We are now drawing near to Chaucer's time, but in Chaucer we look in vain for the recorder; there are, however, many allusions to the flute. For instance, a prominent figure amongst the pilgrims to Canterbury is the flute-playing squire, a fresh, curly-haired young gentleman of about twenty years of age, dressed in the height of

16 Pinkerton, "lift."

15 "Mene"-i.e.," mention."

26 Bannatyne MS., "cytholis" ; Asloan MS., "sytholis "

If Bannatyne MS., " cytharist "; Asloan MS., " sytharist "; Pinkerton, "atherift."

18 Asloan MS., "gyttyrnis."

10 Pinkerton, "ribus" ; Lang, " ribupe."

0 Pinkerton, "rift."

21 Asloan MS., "the trumpe and the talburn."

- Asloan MS., "fydill," a reading undoubtedly preferable to " cythil," that of the Bannatyne MS., the "cytholis" having been already mentioned in the thind line. It can certainly be said of the fiddle that it is played in the fist, or closed hand. Pinkerton, however, gives, instead of "in fist," "and fift"; so that if he is correct the fife is here named.

\$ Asloan MS., "dulset."

"Pinkerton, "schalin."

25 Asloan MS., "claryonis"; Pinkerton, " clarionis."

* Pinkerton, "portatibus"; Asloan MS., "portatiuis" ; as printed for the Hunterian Club, "portatisis."

"Pinkerton, " cymbaellonis"; Asloan MS., "cymbaclanis" ; in the Bannatyne MS., apparently altered in to "cymbaclasnis." Two forms of medizval cymbala-one consisting of plates of metal, the other of small bells fastened together-are described and figured by Engel (" Catalogue of the Instruments in the South Kensington Museum," p. III, and "Handbook of Musical Instruments," p. 105). The instrument here mentioned, however, was, I take it, neither of these, but the cymbalum of a monastery. This was a bell, or pulsatile instrument of some sort, suspended in the cloister and struck with a hammer or mallet to summon the monks to meals in the refectory. The cella or cellarium of a religious house was the cellar; not the wine-cellar only, it included the promptuari.m, or storehouse for food in general. But the word cella was also used to denote the monastery itself, and, more particularly, the open space, interior ambitus, or quad. rangle, round which the cloisters were placed. See Du Cange, s.v.." Cella" soft."

so Bannatyne MS., " so oft "; Pinkerton, " so oft " ; Asloan MS., " so 
fashion, bedecked with flowers white and red, and so well educated that he could write, draw, and dance, the first named being an attainment by no means common in those days outside the Church. His chief occupation was singing and playing the flute, to which he devoted the greater part of the day. But these pastimes were not a mere excuse for idleness; he had acquired a knowledge of music of which few amateur flute players in the present day can boast; " he could songs make and well indite," we are told, a statement implying that he could compose and reduce to notation, if not harmonise, melodies. Nor did his accomplishments involve the slightest taint of effeminacy. He is described as a man of middle height, of great strength and wonderful activity, a good and graceful rider, as well as a jouster ${ }^{20}$-that is, a man skilled in the mock combats with lance and sword so common in the Middle Ages; moreover, notwithstanding his youth, he had taken part in a military raid on horseback in France, and had borne himself well on the occasion.

"Singinge he was a floytinge al the day ; He was as fresh as is the month of May. Short was his goune with slevés long and wide, Wel coude he sit on hors, and fayre ryde. He coude songes make, and wel endyte, Juste and eeke daunce, and well purtreye and wryte."

In "The Romaunt of the Rose," which is a translation from the French, we read of "floytes" and "flautours"; but it is to "The House of Fame " that we naturally turn in the expectation of finding the recorder mentioned, for there Chaucer saw so prodigious an assembly of musicians that they seem to have been as countless as the sands of the sea. Those of them who are classified were divided into three bands, separated from each other by $a^{\circ}$ wide intervalharpers, wood-wind pipers, or flute players, as I shall call them, using the word in its wider acceptation, and trumpeters. It can occasion no surprise that the flute players formed a vast multitude many times twelve thousand in number. Three of them are mentioned by name, but, with one exception, owing to the metamorphoses they have undergone at the hands of transcribers, it is not possible to identify these celebrities with certainty. The first, Atiteris, Atyterys, or Cytheris, may be, and probably is, the great pastoral flute player, Tityrus, with the once common prefix "A " added to the word. ${ }^{\text {so }}$ The second, Pseustis, Procerus, or Presentus seems to be hopeless. Mr. Skeat records the guess that

"A joust was a set-to between two combatants only; a tournament, between several at the same time.

${ }^{20}$ Mr. Skeat proposes Tyrtæus. 
Thespis may be meant, but, as Thespis was a dramatist rather than a flute player, I will hazard the conjecture, in the absence of a better suggestion, that Timotheus ${ }^{\text {el }}$ may be intended, although Pronomus would more nearly resemble Procerus or Presentus. In the third, Marcia, we cannot fail to recognise our unfortunate brother flute player Marsyas. It is true that Chaucer assigns to him the feminine gender, but, notwithstanding the change of sex, there can be no doubt of his identity, for there is an unmistakable allusion to the shameful treatment he received at the hands of Apollo, who, in a trial as to which could produce the better effect on their respective instruments, the lyre and the flute, finding the opinion of the judges going against him, proceeded to use his voice in addition to his lyre, an artifice unworthy of an honest man much less a god, and having thus got a decision in his favour, tied poor Marsyas to the nearest tree and deprived him of his skin without further ceremony.
"Ther saugh I than Atiteris, And of Athenes dan Pseustis, And Marcia that lost her skin, Bothe in face, body, and chin, For that she wolde envfen, lo I To pypen bet than Apollo."

It is disappointing to find that Chaucer says so little about the instruments used. Exclusive of the three groups already mentioned - the harpers, the flute players, and the trumpetersthose who played on " sondry gleës" were " mo than sterres been in hevene," yet not one of their "gleës" is described, or even named, the poet declining to go into particulars in order to save his readers trouble ("for êse of yow "), as well as to prevent loss of time, and sagely adding :-

"For tyme y-lost, this knowen ye,
By no way may recovered be."

a Timotheus was not an Athenian by birth; but he left his home in Boeotia when he became so celebrated as a flute player.

Envfen.-To contend; strive for the mastery. A word now shortened into "vie."-Skrat. See also Richardson's Dic., s.o. "Vie."

"And among other mirth Mr. Ackworth ryed wives, each endeavouring to set his own wife out to the best advantage, he having as they said an extraordinary handsome wife."-PEPY' DiARY, May 18th, 1660.

I ought not to omit to add that Chancer makes mention of performers on wind instruments of Dutch-that is, German-nationality :-

"Then saugh I famous, olde and yonge,

Pypers of the Duche tonge,

To lerne love-daunces, springes,

Reyes and these straunge thinges."

Reyes are round dances-i.e., dances in a ring.-SkBAT. 
The flute players, aithough not so numerous as the un. classified musicians, still numbered tens of thousands; but of all the instruments played in their monster wood-wind band, the names of only five are given, the cornmuse, the shawm, the flute, the lilt-pipe, or lilting-horn as it is here termed, and the straw flute:-
"Tho saugh I stonden hem behinde,"
Afar fro hem, al by themselve, Many thousand tymes twelve, That maden loudé minstralcyes In corne muse and shalmyes, And many other maner pipe That craftely begunne to pipe, Both in doucet and in rede, ${ }^{8 s}$ That ben at feastes with the brede 80 And many floute and lilting-horne, And pypés made of greené corne, As have thise litel herdegromes That kepen bestés in the bromes."

4 $\mathrm{Hem}$ behinde.-Behind them-that is, behind the harp players.

os Both in doucet and in rede.-It has been suggested that doucet may be the name of a musical instrument-the doucetts. In "The Houlate," as we have just seen, there is named an instrument termed the dulsate, or dulset. Another explanation has been offered by Willert, that both doucet and rede are used adjectively - thus, "in doucet " would have reference to dulcet or sweet instruments, such as the various members of the flute family; " in rede," to instruments whose sound is produced by means of a reed. See the note on the passage in Skeat's "Chaucer."

Brede.-Roast meat.-Skzar.

87 The word "lilt " usually signifies a bright, cheerful tune, especially one that sounds high and sharp. "To lilt" is to execute such a tune: it may be used of human singing, of the warbling of birds, or of the sound of a musical instrument, o.g.-

" What shepherd's whistle winna lilt the spring ?"-RAssay.

It is possible that the word $l i l l$, the technical name of the hole in the bagpipe (the thumb-hole at the back of the chanter), with which the highest note of the instrument is produced, is connected with "lilt ":-

"He had the finest finger for the back lill between Berwick and Carlisle."-Willie's tale in Scott's " Red Gauntlet."

To what instrument the designation lilt-pipe, or lilting-horn, was given is uncertain. The shepherd's pipe has been proposed (see Grove's Dic., s.v. "Lilt") and the bagpipe has been named (Jamieson's Scottish Dic.). As the lilt-pipe is here mentioned by Chaucer in connection with the flute, the idea guggests itself that the three-holed pipe played with the tabour may be intended. In favour of this view it may be urged that the tabourer's pipe is called in French the galoubet, a name it owes to its merry, sportive sound, the word being derived, according to Chouquet (Catalogue of the Musical Instruments in the Museum of the Conservatoire of Paris), from the provençal gal. gay or joyous, and oubet for aubet, a diminutive of auböi, hautboy. The name hautboy (haut bris) is particularly appropriate to this little flute, it being an octave above the piccolo, and thus the highest of all wind instruments.

But could the tabourer's pipe be termed with propriety a horn ? It could only claim to be entitled to this appellation on account of its bell or 
Although the word recorder is not to be found in Chaucer, I shall be able to adduce evidence, only presumptive, it is true, but still more or less satisfactory, that it was in use in his time. The Promptuarium, or Promptorium, Pärvulorum is the earliest English Latin dictionary extant. Its compiler, a Dominican friar, of Lynn in Norfolk, unfortunately knew little of, and possibly cared nothing for, musical instruments. He was an anchorite or recluse; and, as such, had been consigned with the consent of his superior, sealed with all the solemnity of a religious service, to a self-imposed imprison-

horn-shaped mouth. The application by Chaucer of the word horn to the lilt-pipe seems to point to another lively, inspiriting instrument, the pibeorn (i.e., pipe-horn), or hornpipe, whose name still survives in the dance called after it. The instrument is usually believed to be named under its usual title in the "Romaunt of the Rose" : "With hornpypes of Cornewayle"; but as some maintain that Chaucer wrote not "horn," but "corn" pipes, the word in the original French being estives, or straw futes (see Skeat's note on the passage), it cannot be said with certainty that "pypés made of greené corne" may not be meant. Like the liltinghorn in "The House of Fame," in " Romaunt of the Rose," the horn or corn-pipe is associated with the flute, the line in which it is mentioned being followed by "In floytés made he discordaunce."

The hornpipe is named in the Promptuarium Paruulorum, where it is rendered into Latin by Palpista on the authority of Robertus Kylwarbi. The word Palpista I cannot discover elsewhere: possibly, however, Salpista may be intended, although Salpista is usually used to signify a trumpeter rather than a trumpet.

In Scotland the pibcorn was known under the name of the Stock and Horn (the stock being the thigh-bone of a sheep or a piece of elder) or Stock-horn. The following quotation from Ramsay's "Gentle Shepherd " shows that the stock-horn was a shepherd's instrument, that a performance on it could be called whistling, and, by inference, that it might be the " shepherd's whistle" of the passage quoted above:-
"When I begin to tune my stock and horn, Wi' a' her face she shaws a cauldrife scorn. Last night, I play'd-ye never heard sic spitel $O$ 'er Bogie was the spring and her delyte;- Yet tauntingly she at her cousin speer'd,
'Gif she could tell what tune I play'd ?' and sneer'd. Flocks wander where ye like, I dinna care, I'll break my reed and never whistle mair."

It is believed by Engel that, under the name of the "corne pipe," the stock-horn is mentioned, along with the recorder, in an enumeration of instruments played by the following extraordinary octet party composed of Scotch shepherds, described in the "Complaynt of Scotland " (1548): "The fyrst had ane drone bagpipe, the next hed ane pipe maid of ane bleddir and of ane reid, the third playit on ane trump, the feyerd on ane corme pipe, the fyfth playit on ane pipe maid of ane gait horne, the sext playt on ane recordar, the sevint plait on ane fiddil, and the last plait on ane quhissel." An interesting and very complete account of the instru. ment is given in a paper by Henry. Balfour, Esq., on "The Old British Pibcorn or Hornpipe and its affinities," in the journal of the Anthropological Institute, Vol. XX., p. I42." See also Stainer and Barrett's "Dictionary of Musical Terms," s.o. "Hornpipe," and Engel's "Catalogue of the Instruments in the South Kensington Museum," pp. 293 and 373, where the lines from Ramsay are quoted. 
ment. Immured in a cell," or "stodyyng howse" (as he would have us understand the word cell to signify), which he could not quit, except in case of necessity, without the permission of the Bishop, he seems to have regarded fluting and fiddling as but vanities of this wicked world. The date of the Promptuarium is known with tolerable certainty to be $144^{\circ}$, just ten years after Chaucer's death.

Both "recorder" and "flute" are found in the lexicon. Recorder, which is distinguished as "lytyl pype," is translated by canula, a word used by Papias when referring to the instrument on which the chorus-flute player (choraules, or choraula) used to play. But, for the purpose of our inquiry, the importance of the entry in the Promptuarium lies in the circumstance that an earlier work, the Campus Florum, is cited as the authority for the rendering. Much uncertainty prevails respecting the Campus Florum, but Leland conjectures that Thomas Guallensis, or Walleys, to whom it has been attributed, flourished about the time of Edward II., whilst two writers give $\mathrm{I} 359$ as its probable date, ${ }^{\infty}$ so that, assuming, as I presume we have a right. to do, that its author mentioned the recorder by name, ${ }^{11}$ we can here trace back the word to the middle of the fourteenth century.

On turning in the Promptuarium to "flute," we should naturally expect to see tibia, fistula, or the Low Latin word flauta, as its equivalent ; but, strange to say, neither of them is given, tibia being reserved for "trumpe" and fistula for " pype," whilst flauta is not named; but in two manuscripts flautorium, a word I have not seen elsewhere, is added. The Latin synonyms for "flute" are three in number. The first, Cambucus, is given on the authority of Robertus Kylwarbi. As Robertus Kylwarbi was made Archbishop of Canterbury in 1272, a Cardinal in 1278, and died soon afterwards, we have now got as far back as the thirteenth

89 The opinion has been expressed that the compiler of the Promptuarium was "starved to death between four walls" " but Mr. Way gives no credence to the story. It is a false inference, he thinks, from the statement that he was "inter quatuor parietes pro Christo inclusus." It seems that the door of an anchorite's abode could not be opened without breaking a seal which was affixed to it, food being handed in at the window.

\& " Canula, fistula, Gallice Flute. Instrumentum musicum. Fapias in MS. Bituric. Choraules, Princeps chori, vel qui Canulus, id est fistulis canit. Chorasle enim G.ace Canula dicitur." Du Cange. The Papias here named, who was an Italian grammarian of the eleventh century, wrote for the instruction of his children a Latin lexicon. According to Way, this lexicon supplied the ground-work of the Dictionary or Vocabularium of Ugutio, Bishop of Ferrara, who flourished in the next century. It is conceivable that the author of the Campus Florum might have derived the word canula from one of these works.

"Appendix to the Promptorium, edited by Way, p. Ixxxiv.

1 Many entries in the Promptuarium afford grounds for believing that English words were used in the Campus Florum. See Way's Preface to the Promptuarium, p. xxv., note $b$, where some of them are named. 
century. The word Cambucus does not occur, as far as I am aware, except in this passage; but Cambuca is found, not, however, as the name of a musical instrument, but of the crozier, or bishop's pastoral staff. Possibly Cambucus may be a scribe's error for Sambucus, this being the name of the elder tree, whose branches, when the pith was removed, furnished (and still furnish for boys) a ready-bored tube for the construction of flutes. Sambuca, which was also used to denote the elder, ${ }^{*}$ is given in the Promptuarium as the Latin equivalent of another wind instrument, the " schalmuse," or shawm, although the name Sambuca was more commonly applied, both in classical times and in the Middle Ages, to a stringed instrument of the harp kind.

The second of the three synonyms for the flute is ydraula. This word appears elsewhere in the Promptuarium as the Latin for "orgon pype," so that we here have a confirmation of correctness of the opinion which has been expressed that "flue-pipe" was, at first, "flute pipe." The authority given for this use of the word ydraula is that of William Brito, who died in 1356 . Thus it would seem that in the fourteenth century organ pipes were called flutes.

Calamaula, the third synonym, is also written in mediæval Latin Calamaulis, Calamellus, and Calamella. It is the word which gave its name to the chalumeau, or shawm (old French, chalamelle). And here there peeps out a vestige of the almost incredible rancour with which the early Christians assailed the flute. It is true that we no longer meet with the fierce invective of Saint Epiphanius, who declares that the hated instrument was modelled in imitation of the serpent through which the Evil One spake and beguiled our Mother Eve, and that he who plays it is no other than Beelzebub himself, as his movements stamp him, for he sways his body and bows his head, these being the gestures of which the Prince of Darkness makes use to show his blasphemy against that which is in Heaven, and to overwhelm in utter destruction the things of the Earth, and them that dwell thereon; nor the coarse insults, too gross for modern ears, of Saint Clement of Alexandria, by whom the flute is pronounced to be fit rather for beasts, or the more brutish of human beings, than for men; nor the refined reproach of the gentle Saint Cyprian, that to strive to talk with the fingers, as he undertakes to show the flute-player does, is an act of ingratitude

4a "Sambuca in musicis species est symphoniarum. Est etiam genus ligni fragilis unde et tibiz componuntur." Isidore, quoted by Du Cange. "Sambuca is the Ellerne tree brotyll, and the bowes therof ben holowe, and voyde and smothe; and of those same bowes ben pipes made, and also some maner symphony, as Ysyder sayth" Trevisa's translation of Bartholomous. (See Hawkins, chap lx, also supra, p. 158, note)

43 Cerone, in a work written in Spanish, and published at Naples in 1613 . includes the Sambuca in a list of wind instruments. (Hawkins, ch. cxxiii.) 
to the Artificer who endowed man with the gift of a tongue. A thousand years had softened the asperity of fanaticism into the mild indictment that the flute was a gugaw. Under cover of an illustration of the use of the word calamaula, the wily "ankyr" introduces a monkish "Versus. Pastor sub caula bene cantat cum calamaula," which he translates thus: "The scheperd vndyr pe folde syngythe well wythe hys gwgawe pe pype." On turning in the vocabulary to "gugaw" in order to ascertain what meaning Brother Galfridus attached to the word, the reader is informed that gugaw is the same as flute, and, it is added, fiddle ${ }^{4}$ (giga)! It is only fair, however, to Friar Geoffrey, to whose meekness and modesty his book testifies, to say that he assigns the responsibility of stigmatising the flute and the giga as gugaws to the "garulus sophista," as Bishop Bale calls him, Robertus Kylwarbi.

"Flute," we may reasonably suppose, came over with William the Conqueror, but "recorder" appears to be a word of English growth. Although it crossed the Channel, for we meet with it in Prætorius, it never took root in foreign soil. How, when, or where it originated it is im. possible, in the present state of our knowledge, to say ; but I have just traced it, without going beyond well known channels, to the fifteenth, and, by inference, to the fourteenth century. Possibly, a special search would show that it was in use at a still earlier period. On the other hand, as we look in vain for it in an Anglo-Saxon dictionary, we may assume that it did not come into existence until after the Norman Conquest.

The instrument to which the name recorder was applied belonged to the fipple flute family. It was distinguished from other members of that family by the number of its holes. At the commencement of the sixteenth century there were, we are told by Virdung, fipple flutes with three, four, five, six,

"4 "Gogaw, idem quod Flowtr, pype, supra in F; et giga, KYLW." On this entry in the Promptrarium Mr. Way remarks as follows: " Various etymologies have been proposed of the word 'gugaw,' in its ordinary sense; 'Cropundia, toyes, or gugawes for children, as rattles, clappers, \&c.' - "Junius," by Higins. 'Babiole, a trifle, whim-wham, gugaw, or small toy for a child to play withall.'-CorG. Skinner suggests Anglo-Saxon zezaf, nuge, or heawras, simulacra, or the French word joyaw. iut gogue or gogaille seems more nearly to resemble it, and signifies, according to Roquefort, 'bagatelle, plaisanterie. Gogoyer, se réjouir,' \&c. It would seem, however, that the word is here given as synonymous with flute, and the inquiry suggests itself whether it had originally denoted some musical instrument, and thence been used in a more general signification. According to Roquefort, there was a wind instrument called gigte, and this statement corresponds with the observation of Ferrarl, that giga, Ital., may be derived from $\gamma$ (rypas, a kind of flute. It is singular that, according to Brockett and Jamieson, a Jew's harp is called in North Britain a gewgaw; but in that instance, as likewise here, in the Promptorium, it seems probable that the word is used merely in reference to that witb which idle disport may be taken, like trifles in childhood." 
seven, eight, and sometimes, but rarely, even more than eight holes. Only such of them as were pierced with not less than eight holes-seven for the fingers and one at the back for the thumb-could with propriety be termed recorders.

Notwithstanding that the holes in use on the recorder did not exceed eight in number (except in the rare case of certain contra-bass recorders), in France the recorder was styled the nine-holed flute (la flate d neuf trous). The misnomer arose from the following circumstance. The lowest hole of the recorder was closed with the little finger. To bring it within reach of that short digit, this hole was placed at the side of the instrument, out of line with the other holes. But there were left-handed recorder players - that is, persons who placed the left below the right hand. A left-handed player would, of course, require the hole for the little finger to be on the left side of the recorder. As in the sixteenth and in the early part of the seventeenth century the recorder was in one piece only, it was not possible for a left-handed player to meet the difficulty by turning the foot, or lowest joint, of bis instrument to his little finger, as did the left-handed player on the onekeyed flute. The recorder manufacturer therefore used to make special provision for a left-handed player. This was done by boring a duplicate hole on the left side of the instrument for the little finger, then closing it with wax, a material which could easily be removed and used to fill the corresponding hole on the other side. Thus, although eight only were required by the player, the recorder was pierced with nine holes.

Nearly four hundred years ago these particulars were not only described in words, but were represented in pictures. In Sebastian Virdung's Musica getutscht, printed at Basle in 1511 , is an engraving (Fig. I), portraying in a diagramatic form a recorder with its eight holes; the duplicate perforation for the little finger being reckoned as one, whilst the

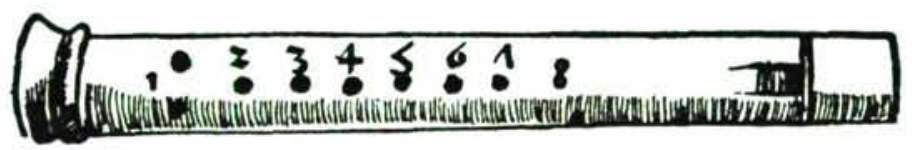

Fig. 1.-Dingram of Recorder, REDUCED, from Virdung.

hole for the thumb (Fig. 1,8 ) is brought by the draughtsman from the back to the side of the instrument in order to render it visible. Another drawing (Fig. 2) explains the use of the duplicate hole. In the lower of the two illustrations the instrument is in the hands of a right, in the upper, of a lefthanded player. 
In the days of the recorder, it must be remembered, the different families of instruments were kept apart, each family constituting a separate band; moreover, just as there was a chest for the viols made to be played together, so was a

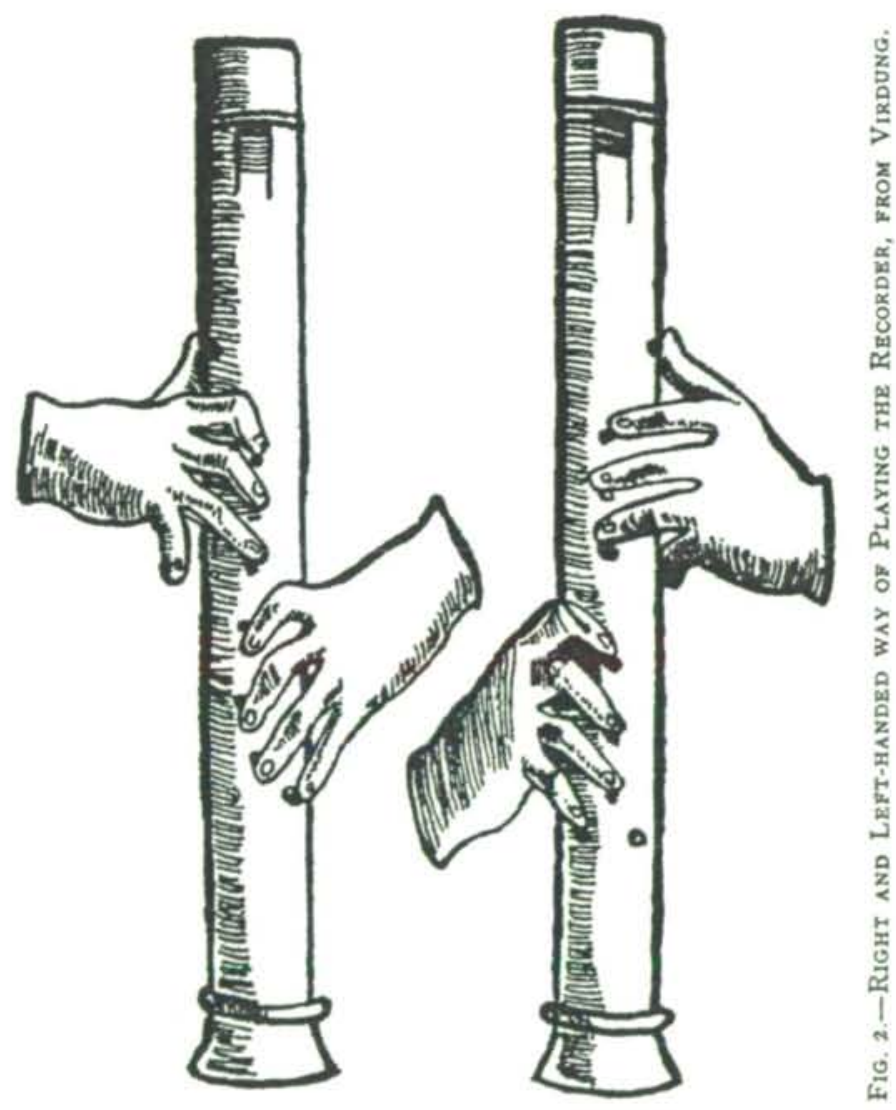

set of recorders kept in a case of its own. Here, again, we get information from Virdung. "Generally," he tells us, " one makes four flutes in one case, or six; this is called a set-two discant, two tenor, and two bass." Further, he 
gives a drawing of the four instruments required to form the recorder quartet (Fig. 3).

On account of the large size of the bass flute, it was not possible for the little finger to reach its hole on that instrument. To meet this difficulty recourse was had to an openstanding key, provision being made for both right and left handed players by furnishing the touch of the key with two cusps. In the drawing of the bass flute from Virdung (Fig. 3), the cusps only are visible, the other parts of the key being concealed from view by a perforated box, or fontanelle, with which it is covered. The box was necessary as a protection for the mechanism, which, without it, would have been extremely liable to injury, not only on account of its delicate construction, but more especially because the spring, which kept the key open, was particularly exposed, as it was not placed under the lever, pressing it upwards, as in the case of the $\mathrm{C}$ and $\mathrm{C}$ sharp keys in the foot of our eight-keyed flute, but passed over the lever and pressed it downwards.

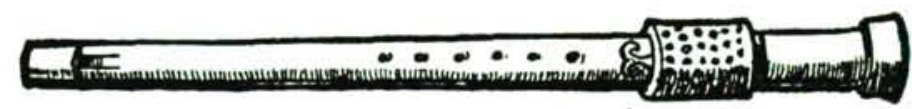

Sloten.

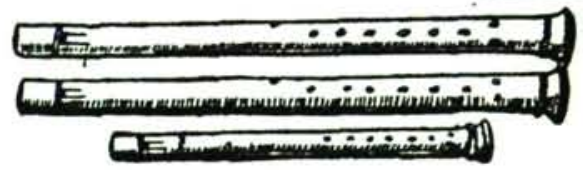

Fig. 3-Recorders for a QUARTEt, RedUced, from Virdung.

It is of importance for the explanation of a key which I shall presently describe that this construction should be understood. I have, therefore, with the kind assistance of Mr. Lehfeldt, had a drawing prepared showing the mechanism of such a key as it appears in a flute in the South Kensington Museum. A glance at it will show that on pressing the little finger on either of the cusps $(b b)$, the first lever would turn on its axle $(c)$, raise the spring (e), and lift the second lever, which, turning on its axle $(f)$, would close the valve $(i)$.

Turning to England in I 511 , the year in which Virdung's work was printed, we find the recorder at the very zenith of its popularity. The throne was filled by a flute player. Henry VIII. was in the twenty-first year of his age and the third of his reign. Richly endowed with mental gifts, the handsomest prince of the time, bluff but affable, gay and jovial, prodigal of his father's treasures, devoted, like 


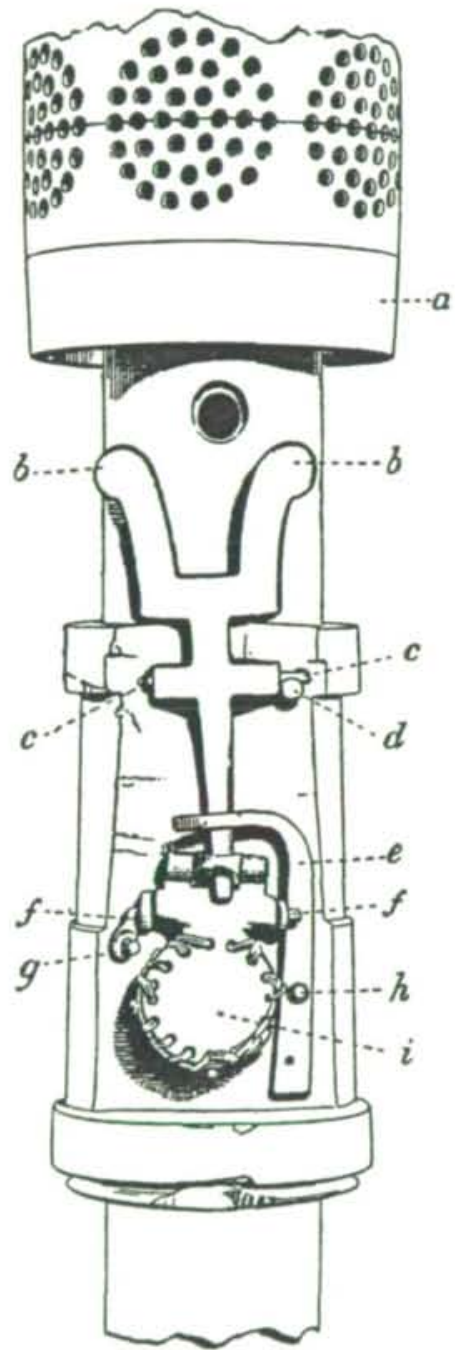

Fig 4.- Mechanism of Openstanding Key.

a. Box moved upwards to show the mechanism; b. b. cuspo of key; c. axle on which the firat lever works; $d$, pin to keep the lever in its place; 4 , spring to keep the key open: f. axle on which the second lever worka ; $\boldsymbol{h}$. pin to lasten the spring to the wood; $\boldsymbol{g}$. pin to fasten the axle to the wood; $i$. valve of key. 
Chaucer's flute playing Squire, to jousting, a martial exercise in which his herculean strength enabled him to prove almost invariably the victor, he was his people's idol. His proficiency in music is usually ascribed to the circumstance that he was trained as an ecclesiastic, it having been only through the premature death of his brother, Arthur, that he came to the throne. It should, perhaps, rather be attributed to the motive which we may imagine to have influenced the Squire in Chaucer-the love of the art. Had he not been designated for the see of Canterbury be would, doubtless, still have been a musician.

It is not for me to remind the Musical Association of Henry the Eighth's skill on the virginals, the lute, and the clavichord; of his sight singing; of his setting of songs and making of ballads; of his "two full masses, everie of them five parts, which were soong oftentimes in his chappell, and afterwards in diverse other places." When musicians hear him reviled and loaded with invective, whilst the benefits we owe to his ability, to his courage, and to his resolution are studiously and ostentatiously denied him, they should call to mind that he gave offence to two classes which those who desire to stand well with posterity, if wise, would propitiate - churchmen, and members of the softer sex; nor should they overlook the significant circumstance that he retained his popularity to the day of his death. More especially am I, as a flute player, bound to repeat the solemn admonition, let him that is without sin cast the first stone at him. Not only was practice on the recorders and flute his daily avocation, ${ }^{45}$ but he was the possessor of a collection of instruments of the flute family the like of which the world has never seen. They were a hundred and fifty-four in number, seventy-six of them being recorders. No less than twenty-seven were of ivory, with tips of silver gilt or of gold itself. They were provided with cases lined with purple, green, black, and crimson velvet. The woods mentioned as employed in their construction are box, walnut, oak, and ebony ; two were made of glass, and one of wood "painted like glass." Van Wilder, the lutenist, had them in his custody, as is shown in the Harleian MS., from which the following list, made after the accession of Edward VI., is taken :-

1s "From thense" (that is, from Greenwich, in 1510 , the second year of his reign] "the whole court remooved to Wiñdsor, there begining his progresse, and exercising himselfe dailie in shooting, singing, dansing. wrestling, casting of the barre, plaieing at the recorders, futs, virginals, in setting of songs, and making of ballads; he did set two full masses, everie of them five parts, which were soong oftentimes in his chappell, and afterwards in diverse other places."-Holinshed, "Chronicles," Vol. III.. p. 557 . 
Harl. MS.

1419. a.

folio 200 .

\section{INVENTORY OF HENRY THE EIGHTH'S WARDROBE.}

\section{INSTRUMBNTES AT WESTMINSTER IN THE Chardgr of Philipp van Wilder.}

Item one Case furnisshed $\mathrm{w}^{\mathbf{k}} \mathrm{xv}$ fllutes in it

Item one Case $w^{*}$ tenne flutes in it the same are caulled pilgrim staves and the same Case furnisshed conteinethe butt vo hole pipes "7

Item one Case $\mathrm{w}^{t} \mathrm{v} \mathbf{y}$ fllutes in hitt $*$

Item $v$ fflutes of Ivorie tipped $w^{t}$ golde enameled black $w^{*}$ a Case of purple vellat garnisshed at both thendes $\mathrm{w}^{t}$ Silver and guilte the same Case furnisshed conteneth but inj hole pipes ${ }^{4}$

Item foure fflutes of Ivorie tipped $\mathrm{w}^{4}$ golde in a Case covered $w^{t}$ grene vellat ${ }^{16}$

16 We are left in doubt as to whether the instruments here named were lip flutes, or fipple flutes with a smaller number of holes than recorders.

$"$ Mr. William Chappell considers that these "Pilgrim staves" were probably six feet long. I am not aware that this idea rests on any other foundation than the circumstance that the staff which forms one of the badges of a pilgrim is usually represented as being of great length. To me, I confess, it would not seem unlikely that the flutes "caulled pilgrim staves" corresponded more nearly in size to the instruments which we term walking-stick flutes, and the French cane flutes (canne fiutes)-that is, flutes constructed in the form of walking;sticks, so that if the owner, when taking a walk (Fétis usually carried one), should feel disposed for a little music, he had.only to have recourse to his stick. But the question arises were the so-called pilgrims' staves lip or fipple flutes? To this question it is difficult to give a satisfactory answer. There were both lip and fipple flutes with six holes. It is true that the walking-stick flutes with which we are familiar, are, for the most part, lip flutes, but the rule is not without exceptions. When 1 was taking notes for the promised, but never published, descriptive Catalogue of the Loan Collection of Instruments shown in the Albert Hall, in connection with the Inventions Exhibition of 1885, there passed through my hands a walking-stick fipple flute. It was of Russian make and bore the maker's name, $C$. Wans-cheld, St. Petersbarg. There werre seven holes in front and a minute thumb hole at the back. The owner, Miss E. A. Willmott, was informed by the Parisian dealer of whom it was purchased that it had been in his shop for fifty years. The Museum of the Conservatoire of Paris contains a "CanneFlûte à bec." as well as a "Canne-Flageolet." Henry VIII. possessed shawms "caulled pilgrim staves."

18 See infra, p 17r, note 51 . 
f. 202. ${ }^{b}$ Item one Case $w^{t} \mathrm{v}$ recorders of Boxe in it

Item viu Recorders greate and smale in a Case couered $w^{t}$ blacke Leather and lined $w^{t}$ clothe

f. 203 Item twoo base Recorders of waulnuttre one of them tipped $w^{t}$ Silver the same are britt redde woodde

Item foure Recorders made of akin bowes

Item vj Recorders of Ivorie in a case of blacke vellat

Item one greate base Recorder of woode in a case of

Item foure Recorders of waulnuttree in a Case
coured $\mathrm{w}^{t}$ blacke vellat

Item 1x Recorders of woode in a Case of woode

f. 205 Item a Case coured $w^{t}$ crimeson vellat havinge locke and all other garnishements to the same of Silver gilte $\mathbf{w}^{t}$ vily recorders of Ivorie in the same Case the twoo bases garnisshed $w^{t}$ Silver and guilte

Item one case of blacke leather $w^{\prime}$ vilj recorders of
boxe

Item a case of white woode $w^{t} 1 \times$ recorders of boxe in the same

Item a case coured $w^{t}$ blacke lether $w^{t} v 1 j$ recorders of woode in it

Item A litle case coured $\mathbf{w}^{\mathbf{t}}$ blacke lether $\mathbf{w}^{*}{ }^{111}$ ] recorders of Ivorie in it

Item one flute and $\mathrm{v} 1$ phiphes of blacke Ibonie tipped withe Silver thone of the phiphes lackinge a tippinge at one ende in a bagge of redde

Item 11] flutes of glasse and one of woode painted like glasse in a Case of blacke leather

Item ij fflutes of woode in a case of blacke Leather

Item inj flutes in a redde leather bagge

49 Probability seems in favour of the flute in the red leather bag, as well as the other remaining flutes in the inventory, being lip flutes. 
What induced Henry VIII. to take up the recorder does not appear; but his father, Henry VII., seems to have shown a partiality to the instrument. Henry VII. is often charged with avarice, but it is only just to mention that no trace of this vice can be found in his treatment of those connected with music ; it is admitted, however, that he was the first English king after the accession of Henry III. whose expenditure was not in excess of his income ; whereas, the blind, unthinking multitude, with whom thrift is a crime, expect princes to squander, whether they be poor or rich, regarding not him who gathers, but him who scatters, as their benefactor. We are assured by a distinguished historian ${ }^{\text {s0 }}$ that Henry VII. often rewarded with generosity, that on occasions of ceremony he displayed the magnificence of a great monarch, that his charities were many and profuse, and are reminded that his chapel at Westminster still remains, a monument of his opulence and taste.

The record of his privy purse expenses teems with instances of his generosity to musicians. Not only were the makers of songs and ballads, the Queen's "fideler," and the "Princesse stryng mynstrels" rewarded, but no matter whither he went, the local band was seldom forgotten. The shamews (shawms) of Madiston (Maidstone), the waits of Canterbury, of Dover, of Coventry, and of Northampton were amongst the recipients of his bounty. Nor were the humblest passed over ; two shillings were given " to a woman that singeth with a fidell." A recorder player is mentioned by name: "To Arnolde pleyer at recorders, 20 shillings." Considering that "Arnold Jeffrey, orgon pleyer," received only ten shillings "for a quarter's wages," the gift was bestowed with no niggard hand.

Under date of February 14, 1492, Henry being then at the Tower, there is a still more remarkable entry: "To the childe that playeth on the records, 20 shillings." We here catch a sight of a youthful genius whose talent met with a truly royal recognition. Two months later, on April 16 , by which time the court had removed to Richmond, there occurs the following: "To Gwillim for flotes with a case, 70 shillings." For what purpose could these instruments have been intended?. They were not for the use of the future Henry VIII., for he was only ten months old. Is it possible that the Solomon of England aspired to govern the ventiges? The flutes were not a common set, if we may judge from a comparison of the price paid for them ( $\varepsilon_{3}$ Ios.) with that given for a pair of clavychords (Ios.), or that at which three lutes were bought (13s. 4d. each), one of them, purchased in 1501, being for my Lady Margaret, another, in 1505, for my Lady Mary, Henry's two daughters. 
To return to Virdung. In addition to the four recorders, Virdung gives a representation of the three-holed flute, better known in England as the tabourer's pipe, which he terms the Schwegel (Fig. 5), and of two other small instruments which

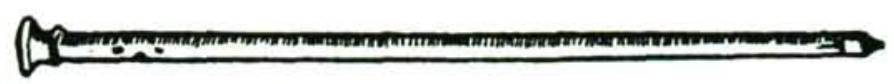

FiG. 5.-SCHWRGRL, REDUCED, FROM VIRDUNG.

we can identify as belonging to the fipple flute family, the mouth being in each case distinctly indicated. They are both furnished with four holes and are named respectively the Ruspfeif, or Black pipe (Fig. 6), and the Gemsen horn, or Chamois horn (Fig. 7). The latter seems, like the ocarina, to have no opening at its lower end.

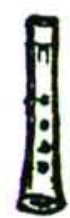

FIG. 6.-RUSPFE1F, FROM VIRDUNG.

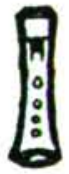

FIG. 8.-RUSPFEIF, FROM Agricola.

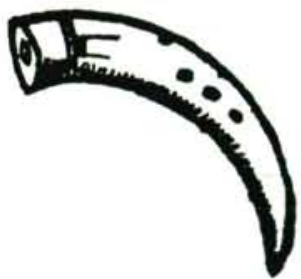

Fig. 7.-GEMSEN HORN, FROM VIRDUNG.

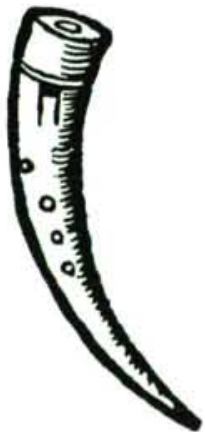

Fig. 9.-GEMSEN HORN, PROM Agricola.

After an interval of seventeen or eighteen years, Virdung's work was followed by the Musica Instrumentalis of Martin Agricola. In the first edition of this book (1528), the instruments for the recorder quartet, the discant, the 
alto, the tenor, and the bass flute, as well as the Ruspfeif and the Gemsen horn, are shown in engravings, differing but little from those of Virdung (Figs. 8, 9, and I0); but from a later edition, bearing the date of 1545 , the Ruspfeif

\section{Dier Floten. Difcantus.}
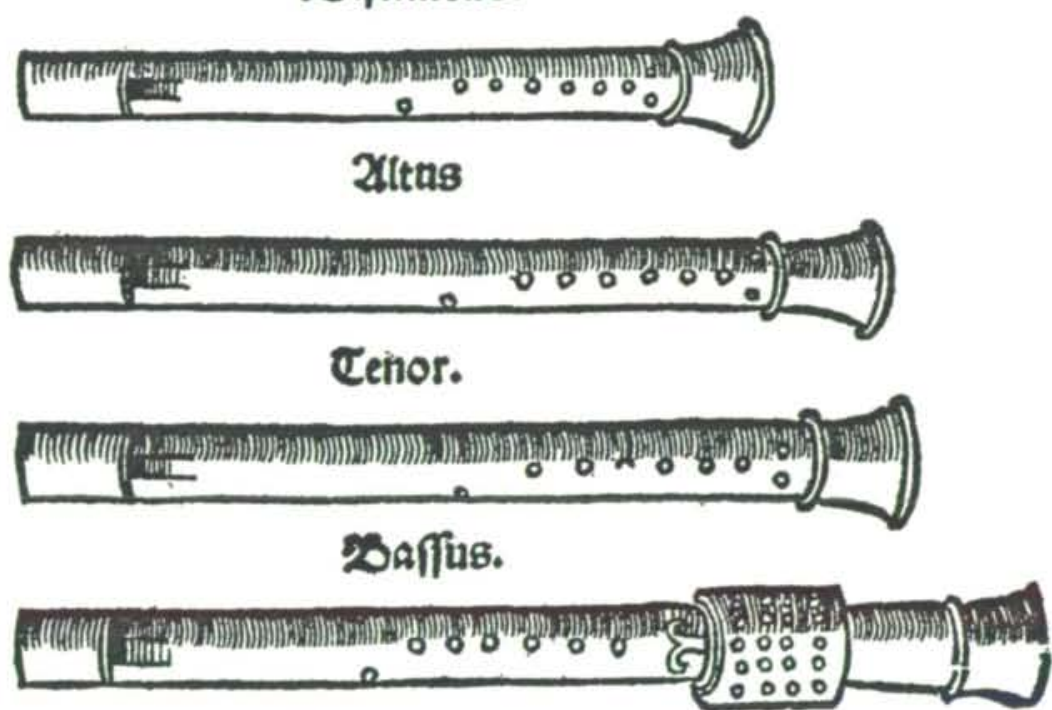

Fig. I0,-Rzcorders for a Quartiti, from Agricola,

and the Gemsen horn have disappeared, their place being taken by another four-holed flute more highly finished, the Klein Flottlein, or (if I may be permitted to coin a word), Little Flutelet (Fig. II.) ${ }^{\text {a }}$

\section{Alein flòttein mit vier lòchern.

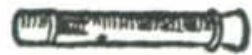

Fig. 11.-The Litrle Fluitelet.

The Germans, it seems, had no special appellation to distinguish the recorder from other fipple flutes; but in France the instrument was called, as I have already said,

n The five flutes of ivory, tipped with gold, in Henry the Eighth's collection may have been Little Flutelets. 
the nine-holed flute. The name had been given to it before 1530, for we find it in Palsgrave's Lesclarcissement de la langue Francoyse, which bears that date. In the EnglishFrench vocabulary contained in the work is the following entry: "Recorder a pype fleute a ix neufte trous." We can place reliance on Palsgrave. He was not, like the compiler of the Promptuarium, a recluse; bred in the country, and only able to express himself in the vernacular he had learnt in his childhood, but a highly educated man, born in London, who had seen much of the world. He was a B.A. of Cambridge and an M.A. of Paris, having studied at both Universities; in addition, he had become incorporated at Oxford, where he took the degree of B.D. Not only did he hold several benefices, including that of St. Dunstan's in the East, to which he was collated by Cranmer, but he was chaplain to Henry VIII. Moreover, he had been appointed instructor in French, or "scolemaster," to the Lady Mary, Henry's younger sister (whom I have just mentioned, incidentally, in connection with a lute), previously to her marriage with Louis XII., and he accompanied her to France on the occasion in 1514 . As he was thus about both the English and French Court, he had exceptional opportunities of making himself acquainted with the recorder and its representative in Paris, la flite a neuf trous.

The last work mentioned in which the recorder was figured was the 1545 edition of Agricola's Musica Instrumentalis. If we pass over a period of seventy-five years we come to the Theatrum Instrumentorum or Sciagraphia of Michael Prætorius (Wolffenbüttel, 1620). In plate IX. of this invaluable record of the musical instruments in use early in the seventeenth century, Prætorius gives a representation, drawn to scale, of the instruments required for a fipple flute band of complete compass (Fig. 12, I.), from the little flutelet to the contrabass or great bass recorder. One member of the fipple flute family-a comparatively recent invention of French origin, the flageolet-we miss; but the tabourer's pipe, here called the Stamentien Pfeiff, which Prætorius connects with England, re-appears. Even this little instrument had a concert of its own, the family being three in number - the discant, the tenor, and the bass. Two of them, the discant and the bass, as well as the tabour and its stick, with which the performer accompanied himself, are shown in the engraving (Fig. 12, 5, 6).

A detailed account of these instruments does not come within either the limits or the scope of this paper; but they have been described by $M$. Victor Mahillon, who, in his "Catalogue du Musée Instrumental du Conservatoire de Musique de Bruxelles" (second edition, p. 239), gives the 


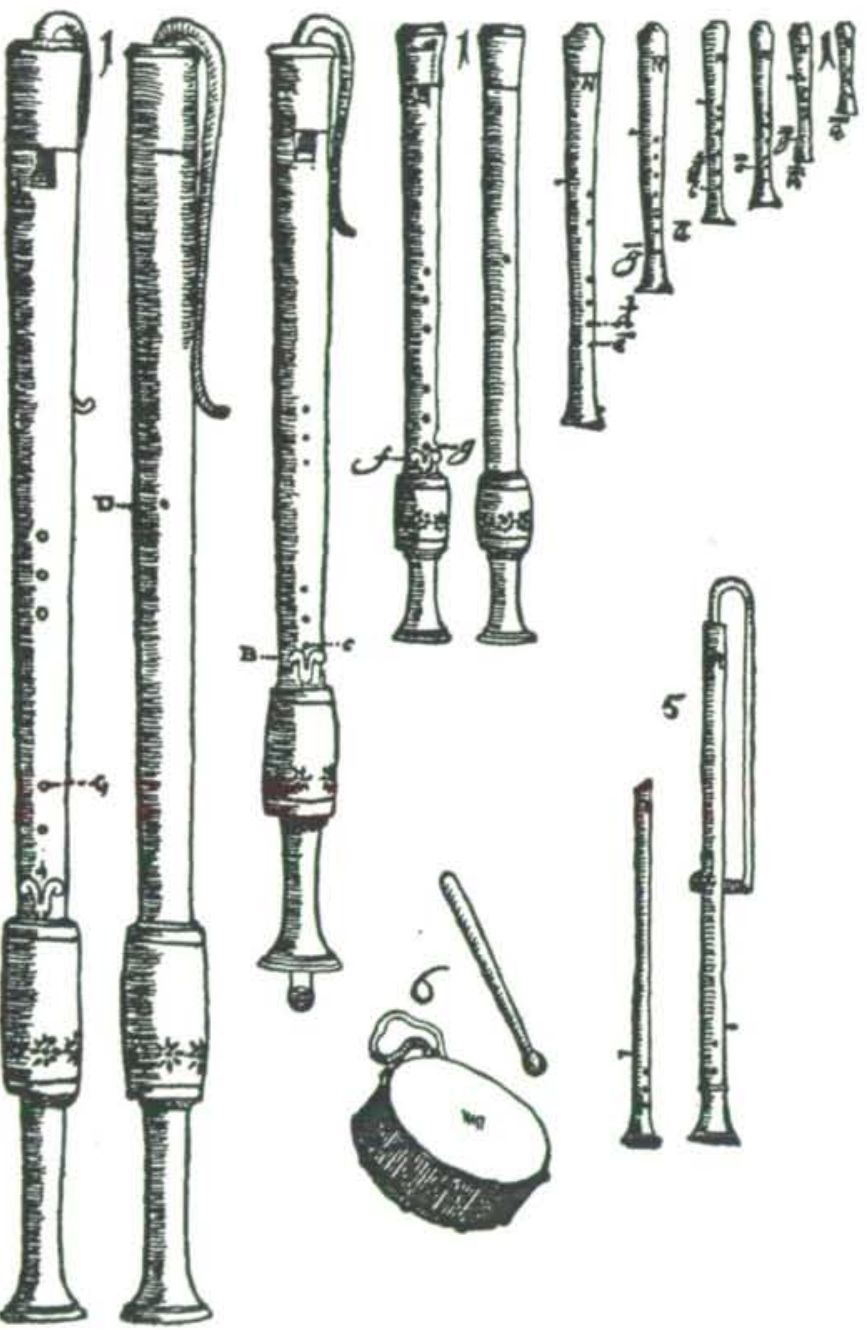

Fio. $12-1$. Fipple Flutes, complete Compass; 5, 6. Pipgs and tabour. From plate iX. op Pratorius. 
key, compass, and length of each. Prætorius enumerates them as follows :-

"1. The Little Flutelet, a Quinta-decima," that is, two octaves higher than the Cornet.

"2. The Discant Flute, a fourth lower.

" 3. The Discant Flute, a fifth lower than the first kind.

"4. The Alto Flute, an octave lower than the first kind.

"5. The Tenor Flute, a fifth lower than the fourth kind.

"6. The Basset Flute, a fifth lower still.

"7. The Bass Flute, a fifth lower than the sixth kind.

" 8. The Great Bass Flute, an octave lower than the sixth kind."

It will be observed that although only eight flutes are mentioned, eleven figures appear in the plate. In two cases, those of the Basset and the Contrabass Flute, it is obvious that two representations of each instrument are given-one of the front, the other of the back. Two peculiarities of construction, not hitherto depicted, will be noticed-the tube with which the bass and the contrabass are furnished to take the breath from the performer's mouth up to the fipple (showr in use in Fig. 19, p. 189), and the foot, which projects from the lower end of the bass, for resting the instrument on the ground.

Prætorius states that a set of fipple flutes, complete in compass, could be purchased at Venice (in the seventeenth century the Italians were the most celebrated makers of wood-wind instruments) far about eighty thalers, and informs us that a full flute band would consist of twenty-one instruments, as follows: two of Nos. $x, 2$, and 3 ; four of Nos. 4, 5, and 6; two of No. 7; and one of No. 8.88 To those who share the opinion of Cherubini, that nothing but two could be worse than one flute, the idea of one-and-twenty flute players all in a row would be indeed appalling; however, I have met with evidence of the existence of a still larger fipple flute band, a band numbering thirty or forty performers. It is to be found in one of the two works published by Burney, giving a description of the tours he made on the Continent in order to collect materials for his "History of Music." "It is true that Burney had no knowledge of the instruments he was describing, but his account of them is so precise as to leave no doubt but that they were intended to be played

82 In the orchestra of Monteverde's "Orfeo" there was an instrument designated "Un Flautino alla vigesima seconda." (See Hawkins, Book XII., chap. cviii.)

68 Syntagma, Tom. II., p. 13 bis.

4 "The Present State of Music in Germany, the Netherlands, and United Provinces," 1773, Vol. I., p 4I The instruments are also alluded to by Fétis ("History of Music," Vol. V., p. 133). One of them is preserved in the Museum of the Conservatoire of Brussels (No. 188). 
together: indeed, notwithstanding their great number, size, and weight, there was a case designed to take the whole of them, a proof that they formed but one set. Referring to his visit to Antwerp, Burney writes :

"After this I went to a very large building on a quay, at the side branch of the Scheld, which is called the Oosters Huys, or Easterling's House; it was formerly used as a warehouse by the merchants trading to Lobec, Hamburg, and the Hanseatic towns; it is a very handsome structure, and has served, in time of war, as a barrack for two thousand men. I should not have mentioned my visiting this building, if I had not found in it a large quantity of musical instruments of a peculiar construction. There are between thirty and forty of the common flute kind, but differing in some particulars; having, as they increase in length, keys and crooks, like hautboys and bassoons; 50 they were made at Hamburg, and they are all of one sort of wood, and by one maker. Casper Ravchs Scratrnbach was engraved on a brass ring or plate, which encircled most of these instruments; the large ones have brass plates pierced, and some with human figures well engraved on them. These last are larger than a bassoon would be, if unfolded. ${ }^{*}$ The inhabitants say that it is more than a hundred years since these instruments were used, and that there is no musician at present in the town who knows how to play on any one of them, as they are quite different from those now in common use. In times when commerce flourished in this city, these instruments used to be played on every day by a band of musicians, who attended the merchants trading to the Hans towns, in procession to the Exchange. They now hang on pegs in a closet, or rather press, with folding doors, made on purpose for their reception; though in the great hall there still lies on the floor by them a large single case, made of a heavy and solid dark kind of wood, so contrived, as to be capable of receiving them all; but which, when filled with these instruments, requires eight men to lift it from the ground. It was of so uncommon a shape that I was unable to divine its use, 'till I was told it."

Let us turn from Germany to France. Mersenne's great work, the Harmonie Universelle, is dated $16{ }_{3} 6$, sixteen years after the Theatrum Instrumentorum of Prætorius;

80 The keys, like those of hautboys, were the keys of the bass recorders already described (p. 164). They resembled the keys of hautboys in their position, function, and in having cusps for right or left-handed players see the drawing of a hautboy on the title-page of "The Compleat Flute Master " (infra, p. I9r). The tubes which reminded Burney of the crooks of bassoons were the pipes for the conveyance of the wind from the performer's mouth to the top of the fute. Burney's remarks show conclusively that the bass fipple flute was an instrument nnknown to him.

so These were Contrabass, or Great Bass Flutes. 


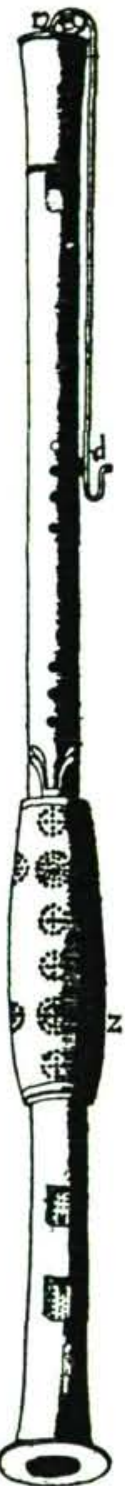

Fio. 13.-Contrabass Flute with Pedals, reduced in size, FROM MERSENNE.

d. Tube to carry up the wind; $Z$. box to cover keys. The circle opposite $d$ represents the thumb-hole at the back. 
but the manuscript is believed to have been finished at least seven years before the work was printed. From Mersenne we learn that in his time the recorder was known in France by three appellations-the flute of England (la fluste d' Angleterre), the nine-holed flute (la fluste à neuf trous), a name which was in use, as we have seen, a century earlier, and the sweet flute (la fiuste douce), the last being the designation most frequently used by that author.

Recorders are divided by Mersenne into two sets-a great and a little set; but as the great begins where the little set leaves off, the complete compass still comprises eight instruments. Here I will again refer you to $M$. Victor Mahillon, who, in the work just cited, enters into the particulars of the two sets, confining myself to one recorder only, respecting which, as it is of exceptional interest, I will ask you to allow me to trespass on your time by saying a few words.

The instrument in question (Fig. 13) was the contrabass of a great set which Mersenne informs his readers was sent from England to one of the kings of France. Mersenne gives no further information on this point, but conjecture would, of course, point to Henry VIII. as the sender, and Louis XII., who married that monarch's sister, the Princess Mary, as the recipient. It was pierced with eleven instead of eight holes, so that three notes could be produced below what would otherwise be its downward limit. One of the three extra holes was closed by adding a second to the ordinary key of the bass flute, already described, ${ }^{b 7}$ the two others by the strange expedient of pedals or levers acted on by the feet. As the performer sat behind the flute (see Fig. 19, p. 189), the pedals were probably either at the sides or at the back of the instrument, not, as represented in the drawing, in front. The size or shape of the holes they closed seems to have excited the astonishment of Mersenne. They were, he declares, like windows.

Mersenne-gives a special drawing of the mechanism of the keys of "this flute, his object being, he tells us, to enable his countrymen "to make others like them." His representation of the mechanism of the two keys closed with the little finger is usually looked upon as a great puzzle, so much so that it is sometimes thought that they were in an injured state when the drawing was made. The difficulty in understanding their action arises partly from the circumstance that Mersenne has made a slip in his description, representing them as kept closed by their springs, whereas they were undoubtedly kept open, partly because an acquaintance with the mechanism of ancient openstanding keys is necessary to render their b7 Supra, p. 164. 


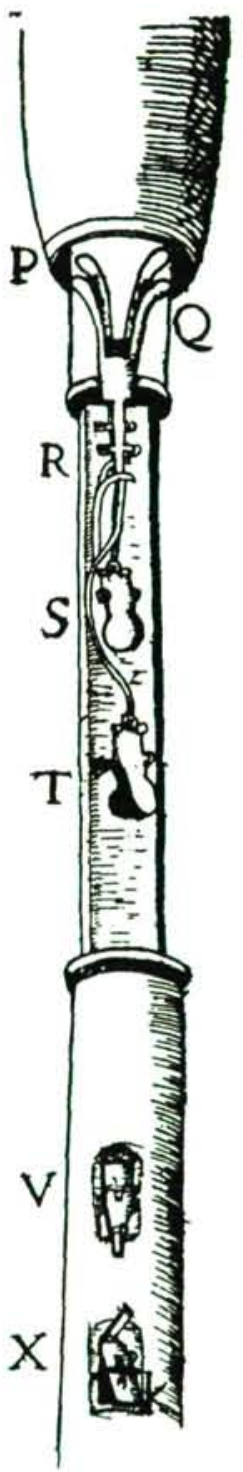

Fig. I4.-Mechanism of Keys of Contrabass Flote, from Mersenne.

P. Box shifted upwards to show mechanism; $Q$. cusps of keys played with the little finger; $R$. ends of springs; $S$. T. valves of keys; V. X. pedal keys. 
construction intelligible. On comparing them with the drawing of the key of the flute in the South Kensington Museum (Fig. 4, p. I65) it will be seen that they are constructed on the same principle, the two curved, wire-like pieces (R.) crossing the levers at right angles, their ends suggestive of the idea that they are broken fragments, being the springs by which the keys are kept open.

A chapter is devoted by Mersenne to the Tabourer's pipe. He calls it the three-holed flute (la fluste a trois trous), the term galoubet, by which it is now usually designated in France, seemingly not being in use in his time. He discusses the surprising extent of its compass, mentions the extremely high notes he had heard elicited from it by an English. man, John Price by name, and suggests that three-holed flutes should be constructed in sets, unaware, apparently, that the idea had been carried out in Germany.

In connection with Mersenne's account of the recorder, I have omitted to mention a circumstance of interest to musicians. There is given in the Harmonie Universelle a composition written for four recorders; it forms one of three examples of concerted flute music to be found in that work, the two others being for German flutes ${ }^{50}$ and flageolets respectively. These examples seem to have been specially composed for Mersenne's book, as illustrations of the method of writing for the several combinations named. Mersenne assures his readers that the composer, le Sieur Henry le Jeune, was well acquainted with the staff (portée), and the compass of such instruments; but as he adds that those who may desire other examples should consult the "Masters of the Art," we may conjecture that Mr. Henry, the younger, was not a professional flute player. I reproduce in fac-simile the recorder quartet, as a short but curious specimen of early seventeenth century instrumental music; I give it in modern dress also, Dr. Turpin having been so good as to put it into our score. Dr. Turpin calls attention to a point in the harmony, consecutive fifths between parts $I$ and 3 in bars 6 and 7.

Whilst the fipple flute was thus quietly developing on the Continent, in England the storm which wrought such havoc with art when Christianity first began to feel her power was preparing again to burst. The clouds gathered in the reign of Henry VIII.; they did not disperse until Charles II. ascended the throne. Had the Puritans succeeded in retaining the upper hand, the flute would have been involved in the fate to which their "squeaking abomination" the organ had already succumbed. On this'point the exponents

The composition for four German flutes, an "Air de Cour," is reproduced in the writer's " History of the Boehm Flute," 3 rd edition, $p$ 216, that for recorders, a "gavotte," overleaf (Fig. 15). 


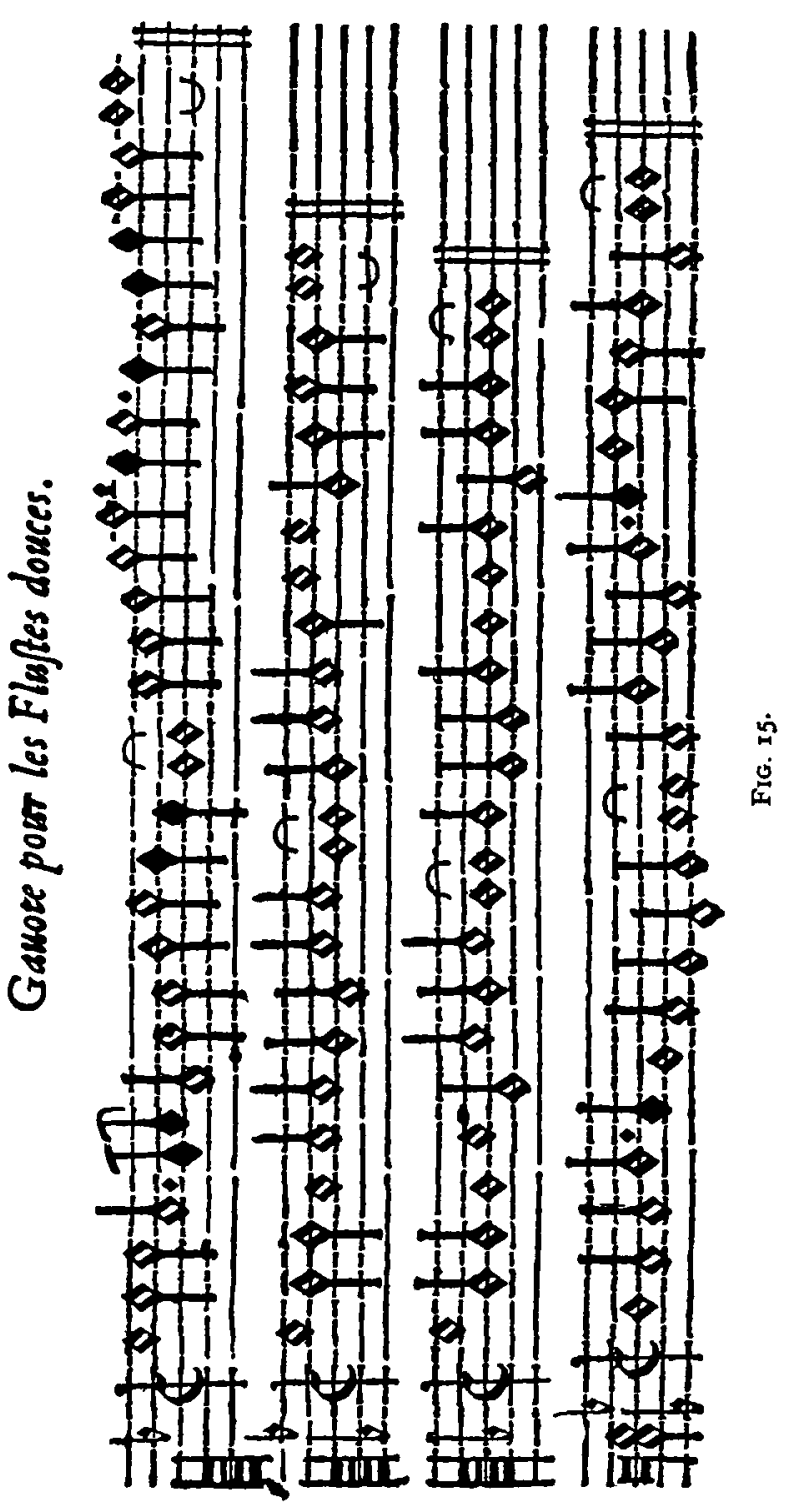




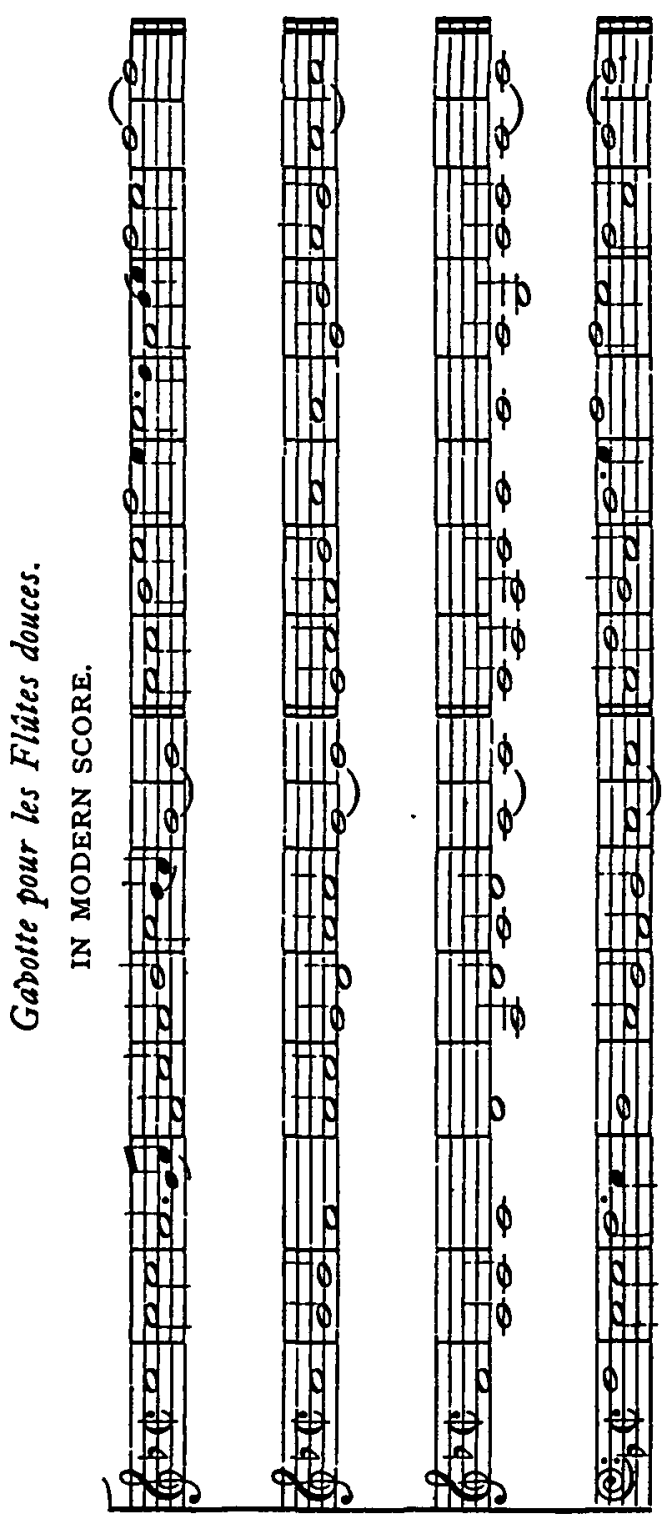


of their opinion spoke with no uncertain voice. Prynne brings up the attack on the flute by St. Clement of Alexandria which I have already mentioned, repeats the dictum of St. Chrysostom that "Cymbals, Pipes, and filthy songs are the very pomps, and hodgpotch of the Devill "; and shows that by the Canons of St. Paul, as given in the Apostolical Constitutions (Book VIII., ch. xxxii.), flute players were to be refused the rite of Baptism." Bilney, who gave his life at the stake for his opinions, "could abide," we are told in Fox's "Book of Martyrs," "no swearing nor singing. - - And when Dr. Thurlby, afterwards bishop, the scholar living in the chamber underneath him," at Trinity Hall, Cambridge, "would play upon his recorder (as he would often do) he would resort strait to his prayer." on Stephen Gosson, a converted actor and playwriter, educated at Oxford, in his essay entitled "The Schoole of Abuse," included pipers, as he termed flute players, in a list of "Caterpillars of a Commonwealth." According to him, piping formed a link in a chain which connected poetry with perdition: "You are no sooner entred [in the Schoole where so many abuses florish] but libertie looseth thee reynes and geves you head, placing you with poetrie in the lowest forme, when his skille is showne too make his scholer as good as ever twangde: he prefers you to pyping, from pyping to playing, from play to pleasure, from pleasure to slouth, from slouth to sleepe, from sleepe to sinne, from sinne to death, from death too the Divel."

Gosson does not confine his attack on the flute to religious considerations, he gives vent to his contempt for the flute music of the time. Referring to Terpander, who is credited with quelling a tumult with his flute, he exclaims: "Terpandrus when he ended the brabbles at Lacedemon neither piped Rogero nor Turkelony." "Homer with his musicke cured the sick souldiers in the Grecians camp, and purgeth every mans tent of the plague. Think you that these

\section{Supra, p. 160 .}

on "Cymbala, tibiæ, et cantica turpia Diaboli pompa et farrago." " Histrio-Mastix," Part I, act v., sc. ro.

61 "If a Stage player, be it a man or woman, a Chariotor, gladiator, race-runner, a fencer, a practiser of the Olympian games, a fluteplayer, a fidler, a harper, a dancer, an alehouse-keeper, come to turne Christian; either let him give over these professions, or else be rejected."

"Scenicus si accedat, sive vir sive mulier, auriga. gladiator, cursor stadii, ludius, Olympius choraules, cytharedus, lyristes, saltator, caupo, vel desistat, vel rejiciatur, Clemens Romanus Const Apost., i., viii., c. 38. Canones Varii Pauli Apostoli, p. 120." Prynne, "Histrio-Mastix," Part I., act vii., sc. 3 .

69 Fox's " Book of Martyrs," edited by Catley, 1837, Vol. IV., p. 621.

63 Rogero and Turkulony were pupular dance tunes in the reign of Queen Elizabeth. The figure of Turkulony, or Turquy longe le basse, is given in the Shakespeare Society's Papers, Vol. I, p. 25. 
miracles could be wrought without playing of daunces, dumpes, pavins, galiardes, measures, fancyes, or newe steynes?" $\mathrm{He}$ is indignant at the complexity of the music and musical instruments of his time. "The Argives appointed by their lawes great punishments for such as placed above 7 strings upon any instrument. Pythagoras commanded that no musition should go beyon his diapason. Were the Argives and Pythagoras now alive, and saw how many frets, how many stringes, how many stops, how many keyes, how many cliffes, how many moodes, how many flats, how many sharps, how many rules, how many spaces, how many noates, how many restes, how many querks, how many corners, what chopping, what changing, what turning, what wresting and wringing is among our musitions, I believe verily they would cry out with the country man, 'Heu, quod tam pingui macer est mihi taurus in arvo."

Before the Puritan tempest which raged in England had died down, instrumental music was beginning to enter on a new phase. Musicians were becoming alive to the importance of the effects which could be obtained by blending instru. ments of different families. Broken music, as the result of such commingling was called, was coming more and more into vogue. The bands of hautboys, cornets, and flutes were breaking up and disappearing, only such members of each family surviving as were best adapted for the new combina. tions. The dawn of this musical era may be discerned in the following remarkable passage in Bacon's "Sylva Sylvarum," a work published in 1627 , the year after the author's death:-

"All concords and discords of music are, no doubt, sympathies and antipathies of sounds. And so, likewise, in that music which we call broken music, or consort music, some consorts of instruments are sweeter than others, a thing not sufficiently yet observed: as the Irish harp and base viod agree well: the recorder and stringed music agree well : organs and the voice agree well, etc. But the virginals and the lute; or the Welsh harp and the Irish harp; or the voice and pipes alone agree not so well; but for the melio. ration of music, there is yet much left, in this point of exquisite consorts, to try and inquire." "The melioration of music" resulting from the experimental inquiry in the "point of exquisite consorts," to which Bacon here directs attention, led to the development of the modern orchestra.

The change was soon reflected in books of instruction. In 1683, rather more than half-a-century after the "Sylva Sylvarum " had issued from the press, Salter's often named "Genteel Companion, or Exact Directions for the Recorder," made its appearance. Here we find no mention of the o1 Bacon's "Natural History," Century II. 278 


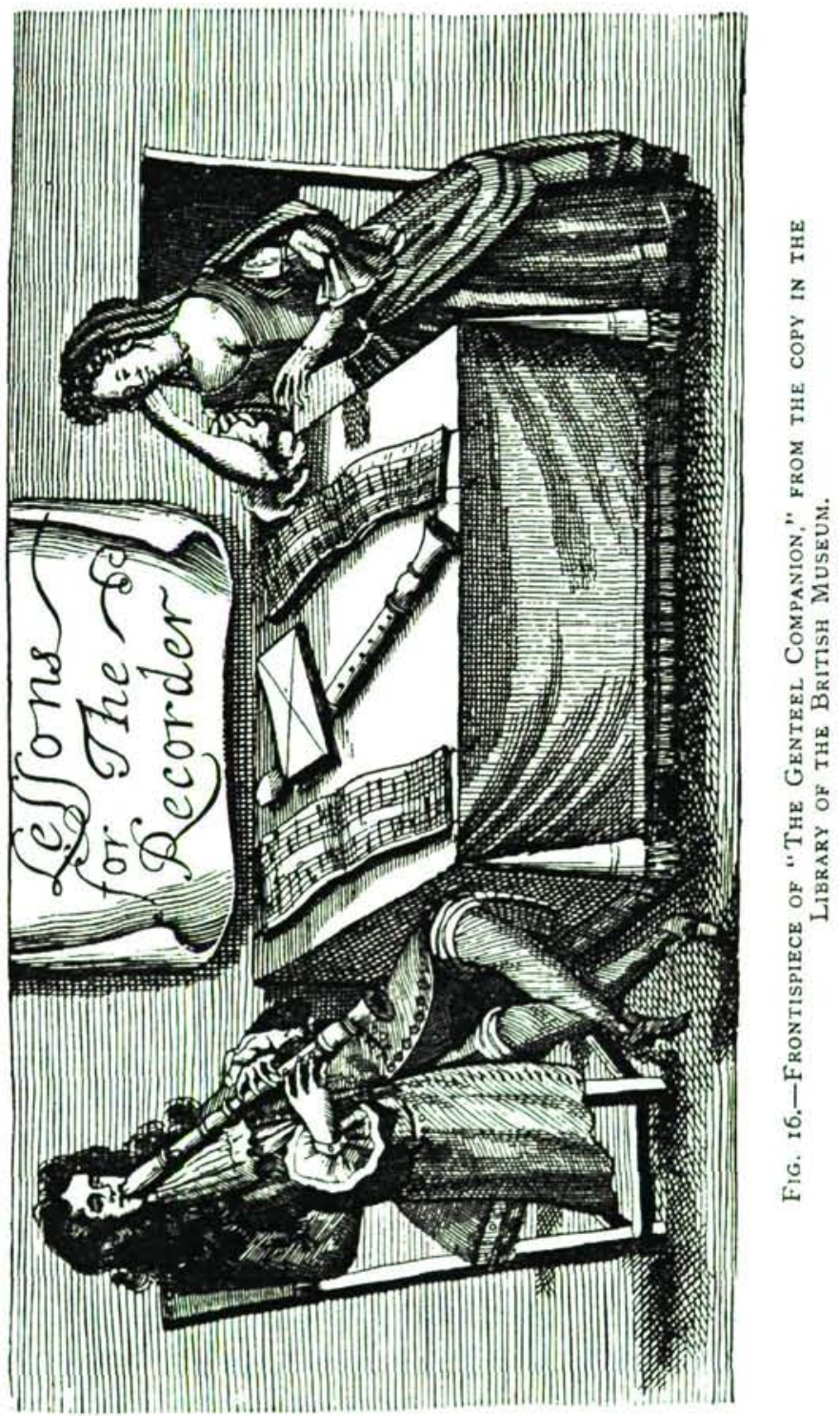




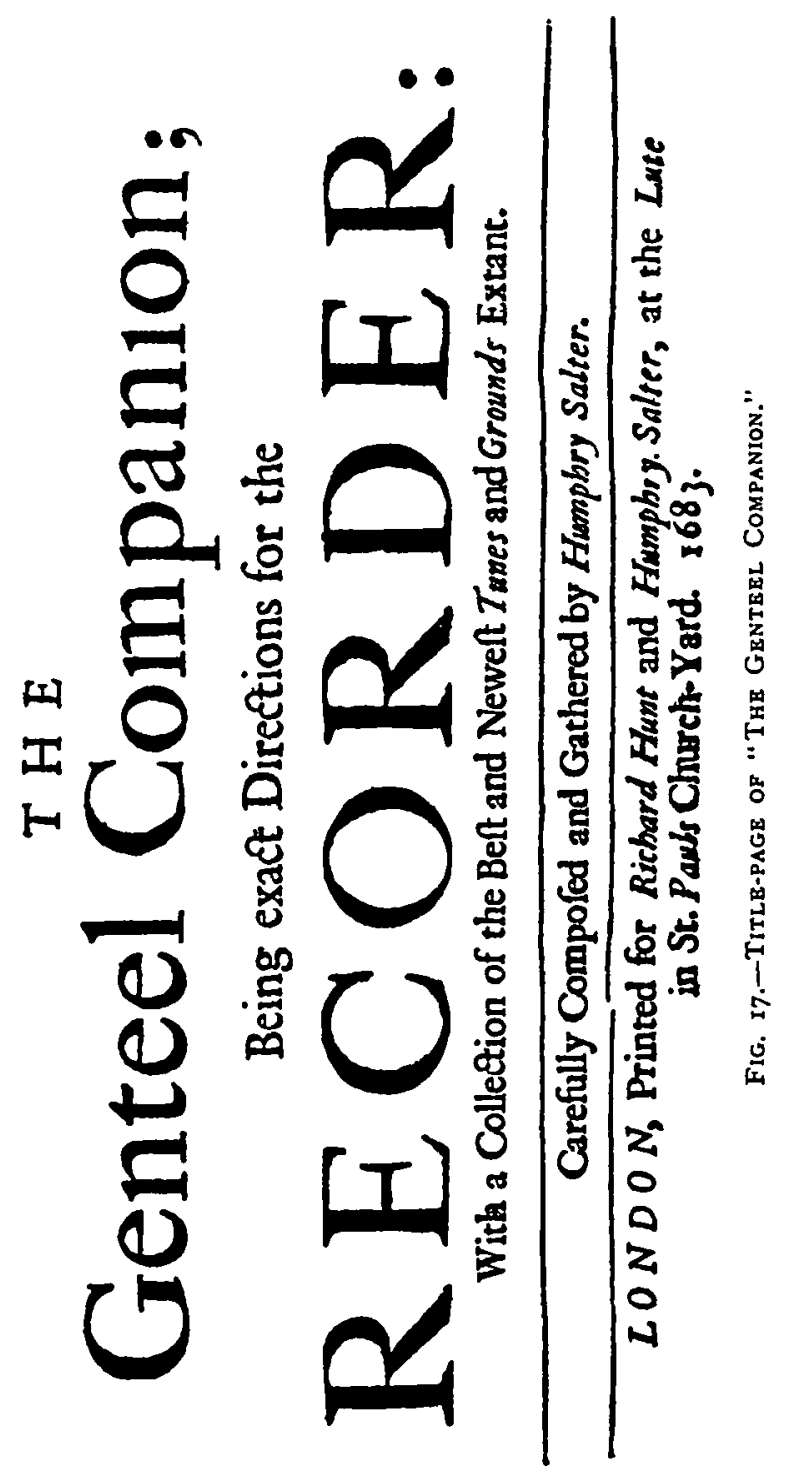


Discant, the Alto, the Tenor, or the Bass recorder; the family is reduced to a single member. On examining the survivor, as portrayed in the frontispiece of the copy of the work in the Library of the British Museum (Fig. 16), we observe that the duplicate hole for the little finger is no longer needed, the tube being constructed in three separate pieces, so that the position of the hole can be changed at will, to suit the requirements of a right or a left-handed player, by turning the foot, or lowest joint, in which it is pierced.

The recorder is in the hands of a gentleman arrayed with the flowing periwig, the many-buttoned coat, the lace cravat, the ruffles, the breeches, the stockings, and the shoes of the period. He is seated on a Cromwell chair, with his legs negligently crossed, his attitude indicating that he believes himself to be a perfect master of the instrument on which he is playing.

The gentleman is not alone. On the opposite side of a table at which he is sitting is a lady, presumably his wife, to whom he appears to be giving instruction. She, also, is elegantly attired. Her gown is low, with hanging sleeves, the under-sleeves, which are full, puffed, and frilled, being, seemingly, of cambric, or a similar fabric, whilst a panier attached to the bodice, after drooping in graceful folds at the side, is caught up at the back, the end falling almost as low as the hem of the petticoat. Her hair, turned back at the sides, is dressed in a projection behind; curls, natural or artificial, over-hanging her forehead. Over her head is a mantilla ; eardrops adorn her ears; a necklace of pearls, such as the brush of Lely so often depicted, surrounds her neck; and gloves, or mittens, seem to envelop both hands and arms. She has laid down her flute, and is leaning her head on her right arm, the elbow resting on the table. Her eyes are fixed on a music book which lies open before her, whilst her left hand is raised with a gesture of rapt attention as she listens to the notes which we may imagine to be issuing from the gentleman's recorder, as if endeavouring to profit to the utmost by the lesson she appears to be taking.

In connection with this frontispiece, I will ask your permission to be allowed to mention a circumstance, in my own experience, which seems to have a bearing on the question we are considering - the supersedure of the concerts of recorders. In the Library of the British Museum is a work entitled "Thesaurus Musicus." The title-page (Fig. 18) is ornamented with an engraving, labelled "Lessons for the Recorder." It represents four half-fledged angels, assembled at a table for a recorder quartet. One of the most important lessons for the recorder was how to transpose and arrange 


\title{
THESAURUS MUSICUS:
}

\author{
B E I N G, A \\ COLLECTION of the Neweft SONGS
}

PERFORMED

At Their Majefties Theatres; and at the Conforts in Viller-ftreet in York-Buildings, and in Cbarles-ftreet Covent-Garden.

W I T H A

Thorow. Bals to each SONG for the Harpficord, Theorbo, or Bafs Fiol. To which is Annered

A Collettion of Aires, Compofed for two Flutes, by feveral Mafters

\section{THE FIRST BOOK.}

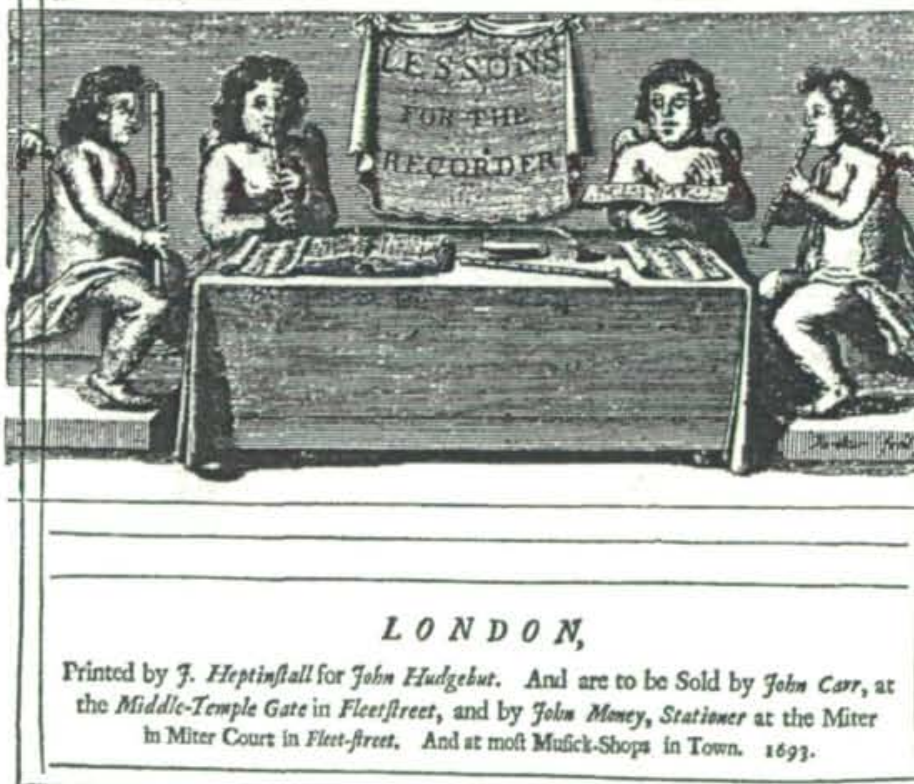

Fig. 18.-Tithe-page of Hudgenut's "Thesaurus Musicus," reduced. 
music for the instrument. In the engraving, two of the angels appear to be playing over some manuscript parts on their respective flutes, whilst a third has placed his recorder on the table and is reading a music book which he holds in his hand, as if comparing its contents with what is being played. A pen and ink seem to suggest, either that the parts have only just been written, or else that provision had been made for corrections or alterations, in case any should be required.

When I first became acquainted with this engraving, now a long time ago, recognising its importance in solving the enigma of the recorder, I obtained permission to have a copy of it taken (Fig. Ig). I did not, of course, fail to perceive that the engraving could not have been designed for the place it occupied; it was unsuited to the work, as well as too broad for the page. It was obviously intended, as the label showed, for a frontispiece to a book of instructions for the recorder; the excuse for inserting it in Hudgebut's "Thesaurus" being, seemingly, that the book contained some duets for two flutes. ${ }^{e s}$ A note I made at the time shows that I had observed that it was dated 1682, the year before Salter's "Genteel Companion" was published, and had remarked that, as it was exactly adapted in point of shape and size for the frontispiece of that work, it was allowable to suppose that it might have been designed and engraved for the purpose, but that, as recorder concerts had become things of the past, it was afterwards rejected to make way for a design more in accordance with the altered state of flute playing, the discarded plate being utilised by Hudgebut for the ornamentation of his title-page. Some years afterwards (it was in June, r8gI) I happened to be at Oxford, when, on Mr. Taphouse showing me a copy he possesses of "The Genteel Companion," what should I see but this very engraving forming its frontispiece! At least one copy, then, of "The Genteel Companion " had been issued contain. ing the engraving of the recorder quartet party. But here a question arises. May not the engraving have been cut from the title-page of Hudgebut's "Thesaurus" and introduced into Mr. Taphouse's "Genteel Companion" to make up an imperfect copy? This is a matter on which it is not for me to express an opinion; it is a point for experts to discuss. I may say, however, that a comparison I have recently made of the two copies of "The Genteel Companion," that belonging to Mr. Taphouse and that in the British Museum, shows that they differ in other particulars besides the frontispiece, and that Mr. Taphouse's copy

65 The duets are by Mr. Pesable, Mr. Robert King, Mr. Godfrido Finger, Mr. John Banister, and Mr. Keen. 


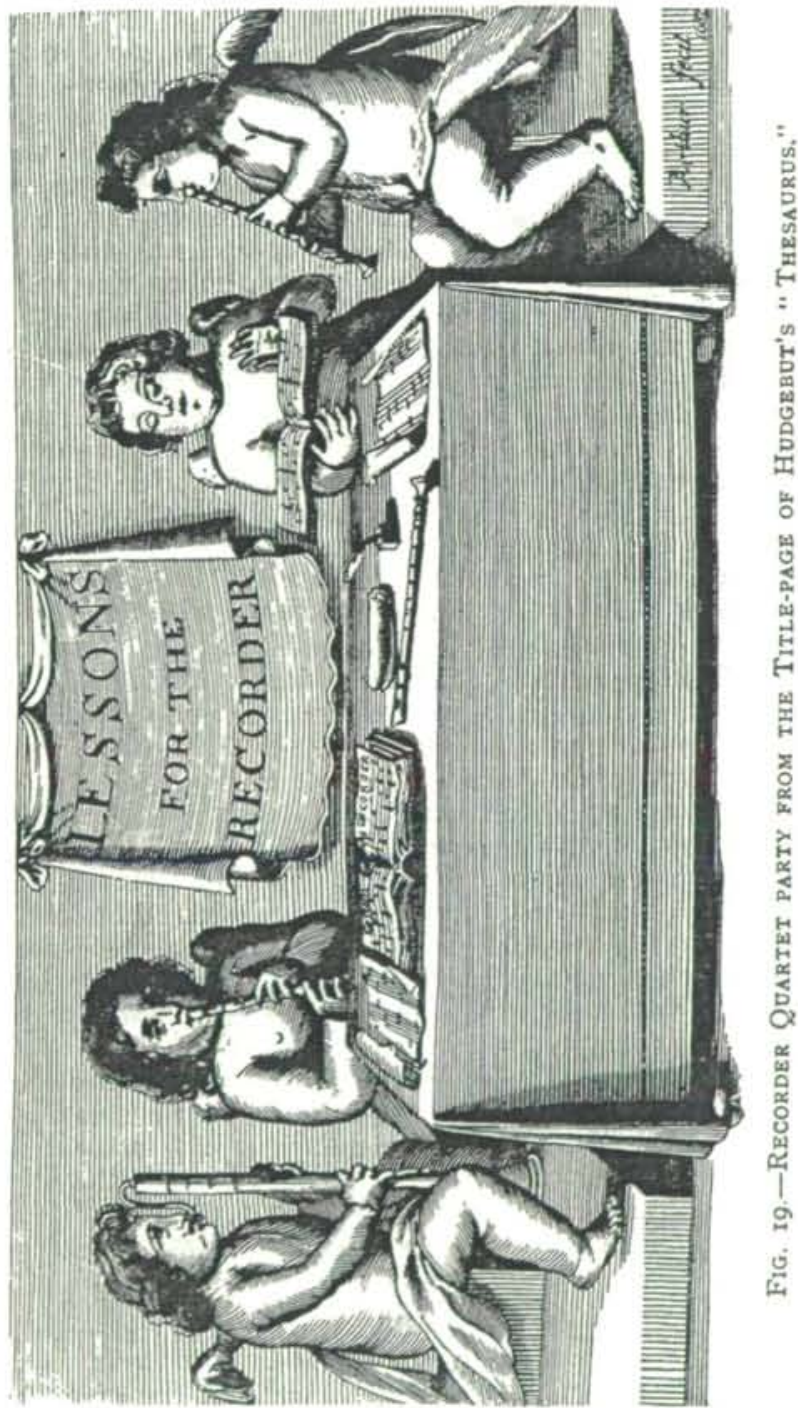


belongs, beyond all doubt, to an earlier issue of the work. I have it here, Mr. Taphouse having been so good as to entrust me with it, and I shall have great pleasure in showing it to any of you whom it may interest.

The change to which I am referring was not the only change which the recorder was destined to undergo. The change of which I have now to speak is a change to which musical instruments are especially liable-a change which renders a satisfactory investigation of their history generally difficult and sometimes impossible-a change of nomenclature: the recorder was about to drop its name and revert to its old appellation of flute. At first, when the change commenced, the instrument was styled indifferently the recorder or the flute. Here, again, information comes to us from books of instruction. A work in the Library of the British Museum bears the following title: "The Delightful Companion: or, Choice new lessons for the Recorder or Flute." Again, an instruction book belonging to $\mathrm{Mr}$. Taphouse (Fig. 20) is entitled "The Compleat Flute-Master," but ielates to the art of playing "the rechorder." Soon "recorder" entirely disappears. "The Music-Master," which came out in 1730 , is a collection of codes of instruction for different instruments-the hautboy, the German flute, the violin, and others. Neither in the title-page (Fig. 22) of the instructions for the flute, nor in the instructions themselves, does the word recorder occur, whilst the frontispiece (Fig. 2I) shows that the instrument is, in its essentials, no other than that represented in Salter's "Genteel Companion." We have a somewhat later example in Tyther's "Complete Flute Master" (Figs. 23 and 26). So rapid and so complete had been the metamorphosis that neither Hawkins nor Burney, the former born in 1719, the latter in 1726, seems to have entertained the faintest suspicion that "the flute," with which they were so familiar, had once been known as the recorder. ${ }^{\infty}$

It was not only in England that the recorder had changed its name, in France also a new appellation had been assigned to it. It is true that it was still termed la flate douce, but la flate d'Angleterre and la fiate d neuf trous had been abandoned to make way for la flate d bec, " or the beaked flute. By 1735 this expression had found its way into England, or at least

60 Some instruments shown as recorders would be more correctly named if they were termed flutes, as they are not old enough to have been called recorders, either by those who made or those who played them.

or According to Littré (Dic., s v. "Flûte "), the term flutte à bec is applicable to all instruments the end of which is placed in the mouth: "Flutes à bec, tous les instruments comme la clarinette, le hautbois et surtout le flageolet, où il y a une extrémité qui se met dans la bouche." 


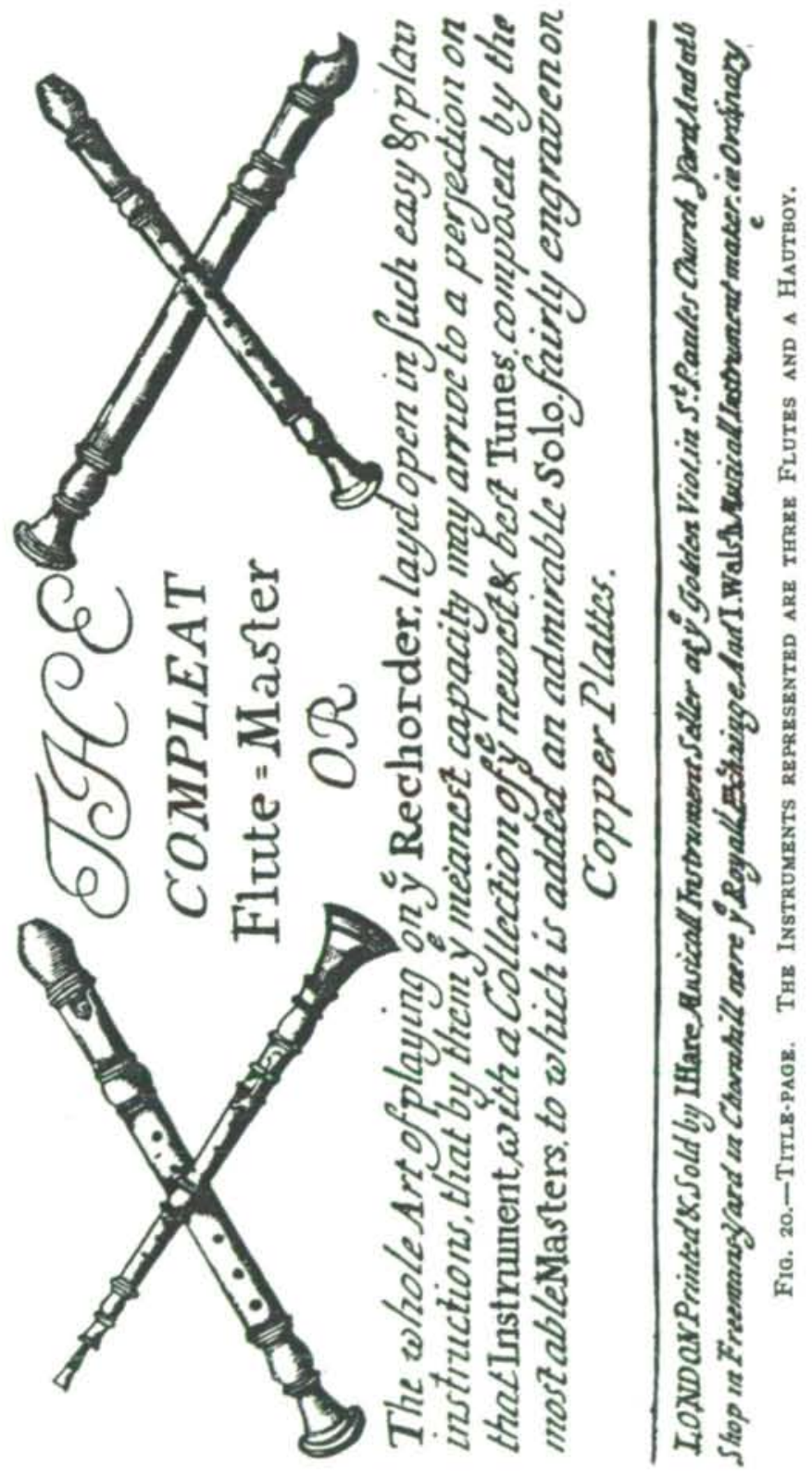




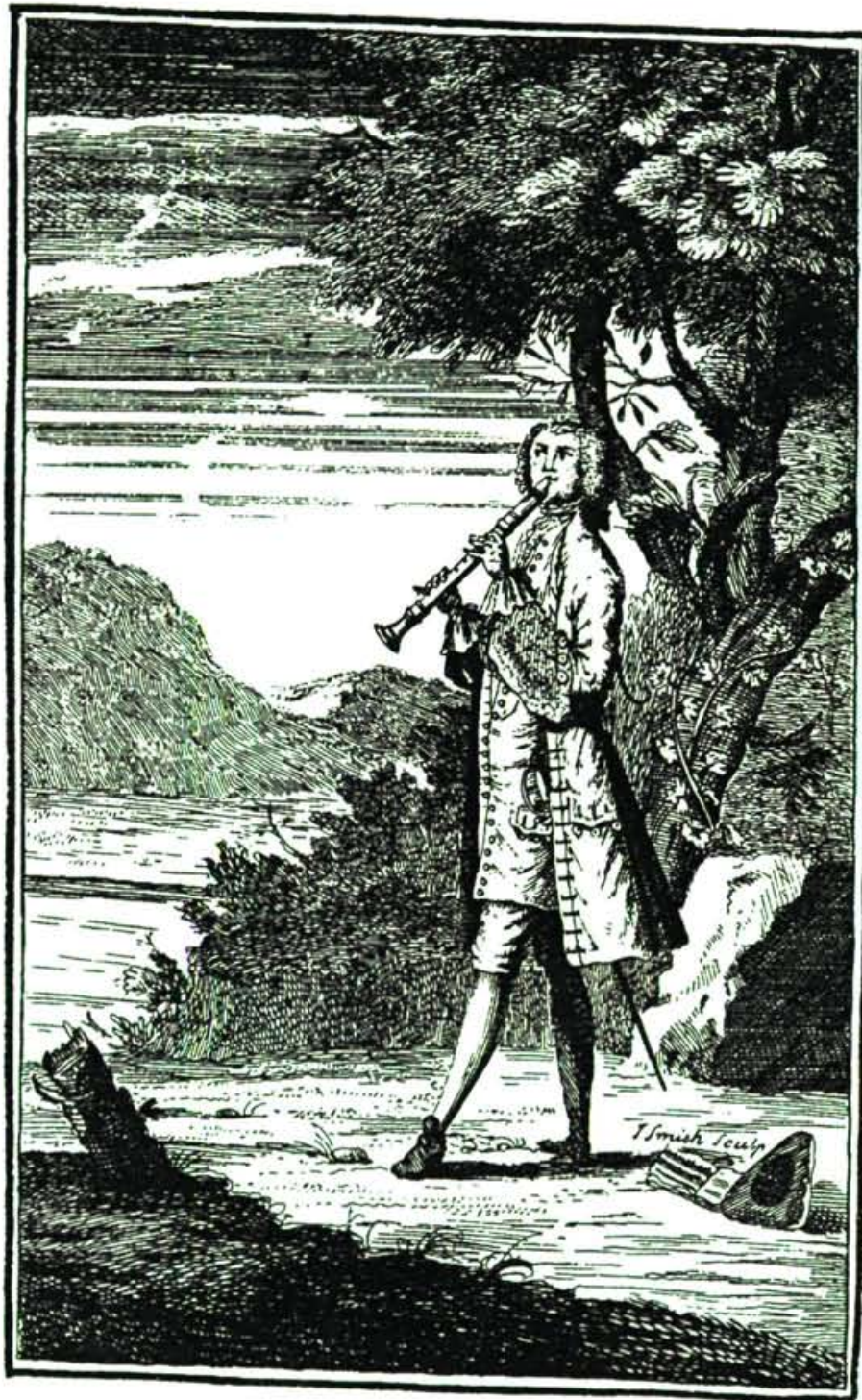

F1G. 21.-FroNTISPIECE. 


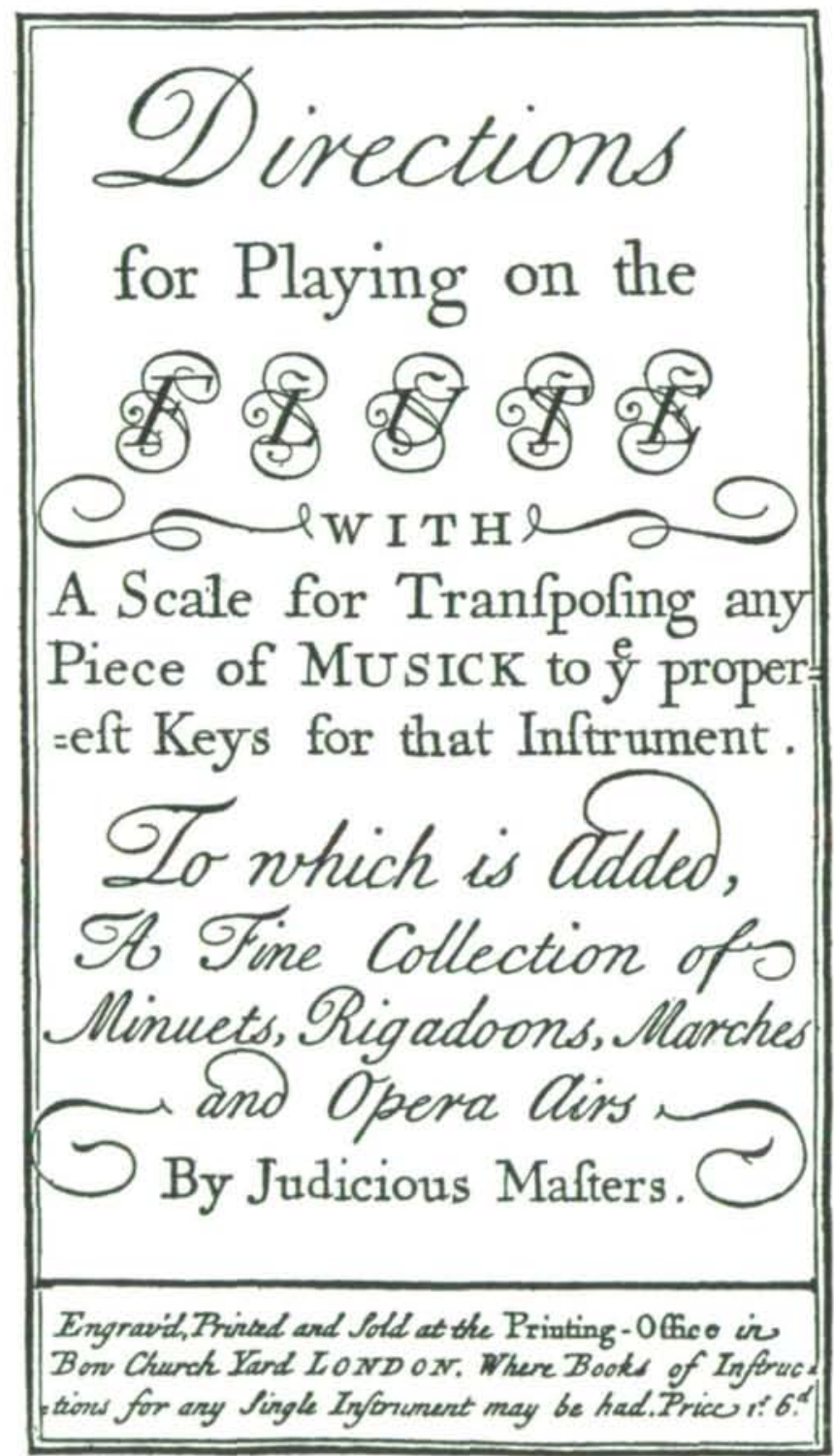

Fig. 22.-Titherpag. 
194 Literature Relating to the Recorder.

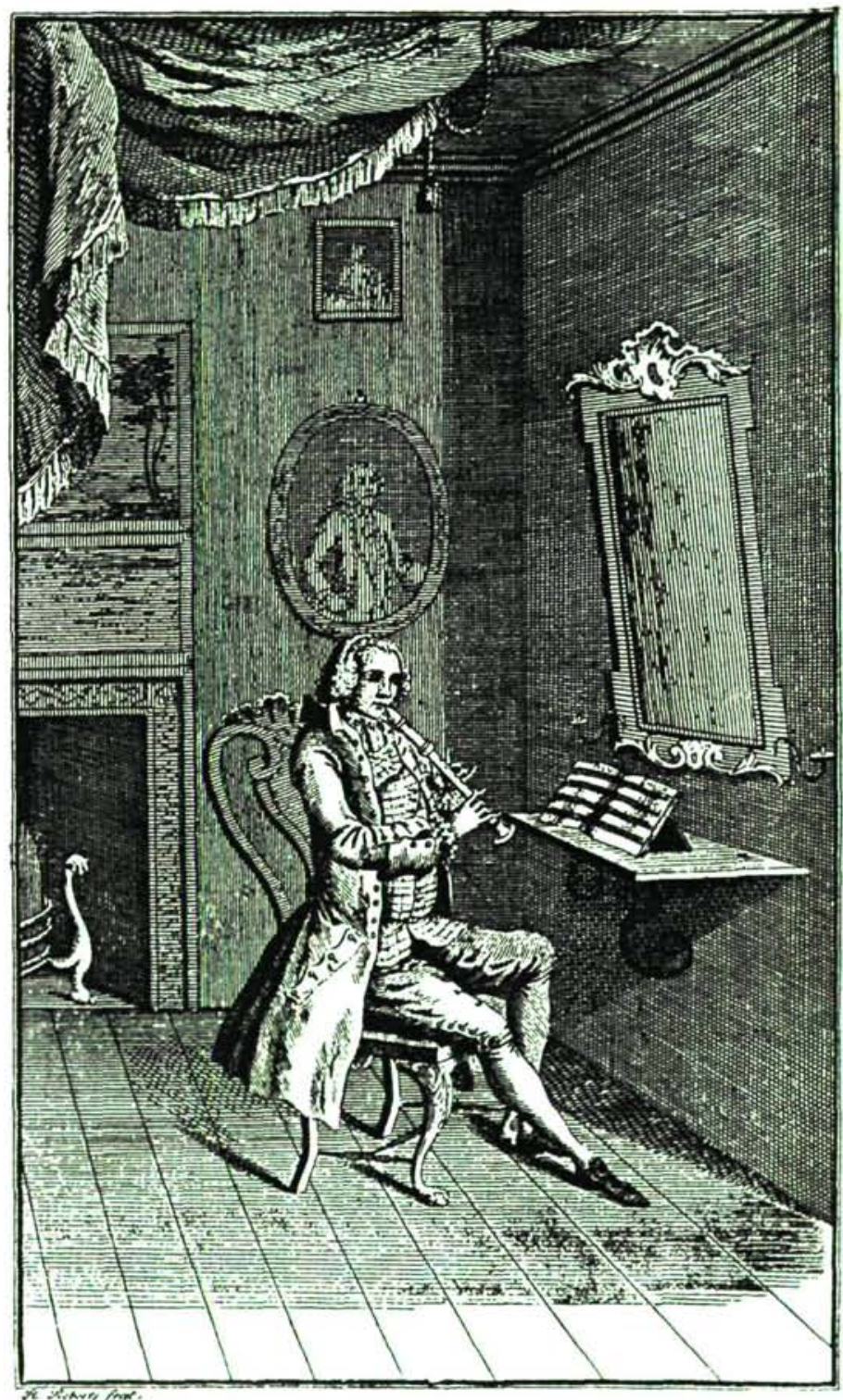

Fig. 23.-Frontispiece. 


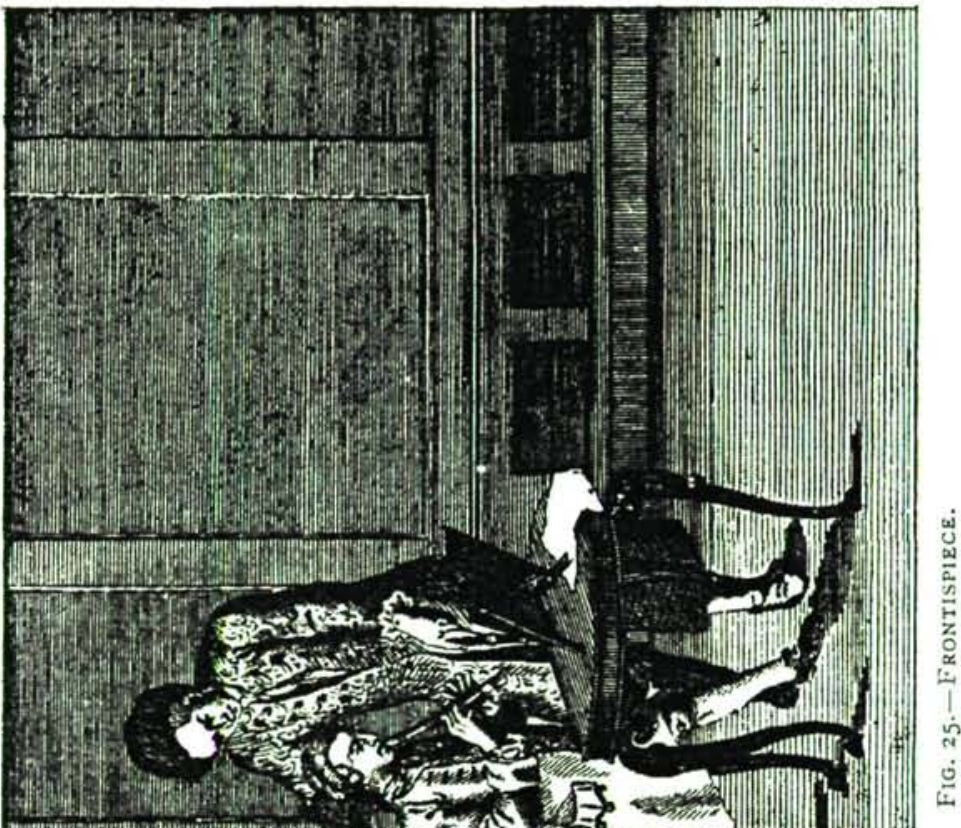




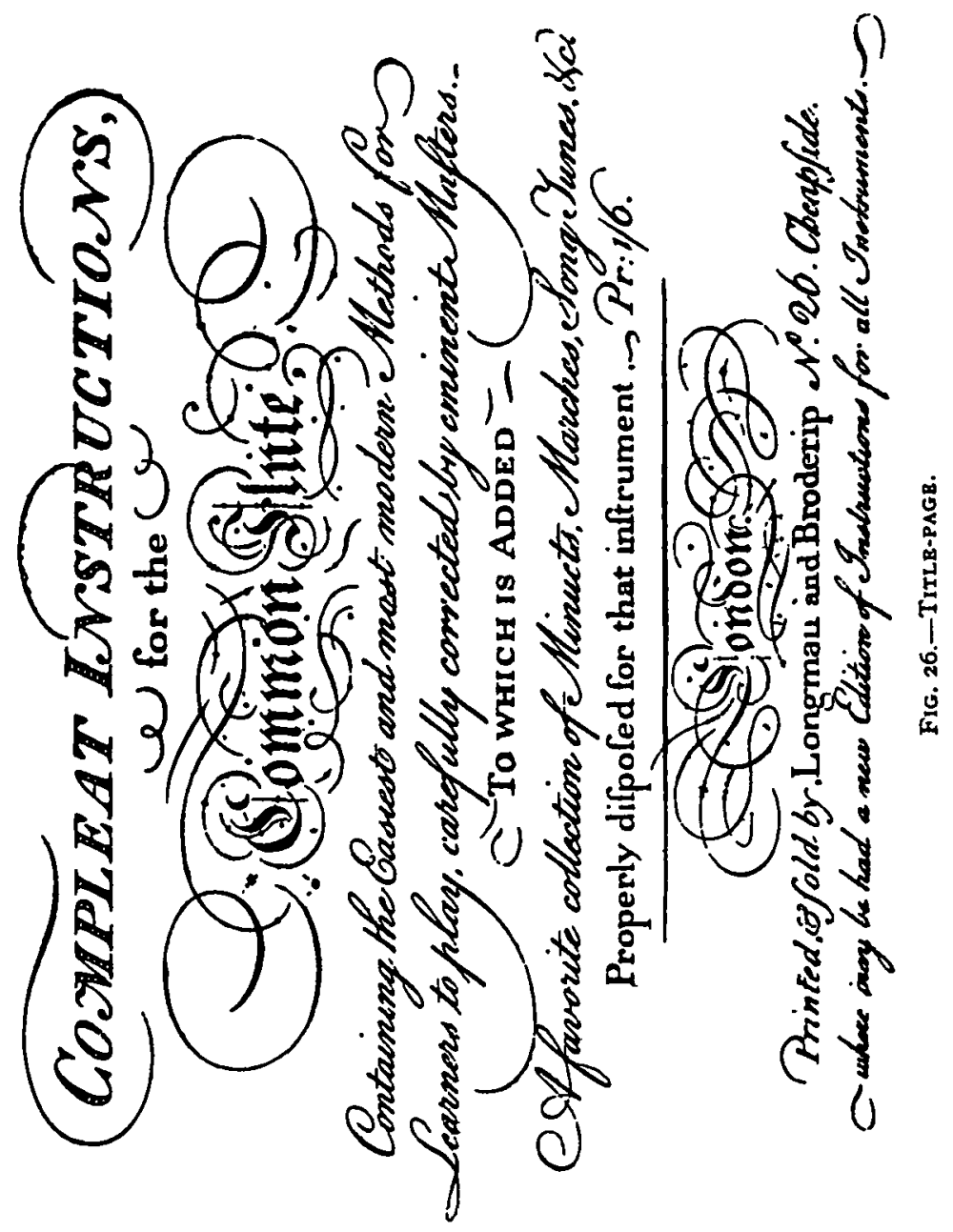


into Scotland. It does not, however, seem to have come into general use in this country in the eighteenth century, notwithstanding that Hawkins pronounced it to be "the most proper and discriminating appellation" for the instrument ; but in the present day it is often employed.

Another change- the last, alas ! -extinction, was awaiting the recorder. Just as the harpsichord was giving way to the pianoforte, so the recorder, yielding to the inexorable law of the survival of the fittest, was succumbing to its rival the German flute. The surpassing beauty of its tone failed to ward off its impending fate, the greater command over sustained notes and power of infuencing intonation possessed by the lip flute proving too strong to be resisted. An indication that its career was drawing to a close is to be found in another change of name; the German flute had usurped the title of "the flute," the old favourite having descended to the appellation of "the Common flute." For proof of this we can again appeal to a book of instructions - one published by Longman and Broderip in the reign of George III., on the title-page of which (Fig. 26) it is so styled. Its knell was now about to sound; with the harpsichord it scarcely survived the eighteenth century.

In dealing with Sir John Hawkins, it is necessary to premise that he was under the influence of a dislike to the flute so violent that it fell little short of a monomania. The very name of a flute, or a flute player, was to him a red rag. Even the ancient Roman Temple flute players, whose duties in the ritual of their religion were far more important than are those of Cathedral organists in the services of our Church, the importance of their duties being equalled by the honour in which they were held, are pronounced to be remarkable for their

os Flate a bec is found in the following elegant dedication of "Airs for the Flute, with a thorough Bass for the Harpsichord," of that date:-

Madam,

To the right Honorable yo Lady Gairlies.

The following Airs having been composed by a Gentlemran for your Ladyship's Use when you began to practice the Flute a Beque; I thought I could not chuse a better Subject for my First Essay, as an Engraver of Musick, than these Airs : as well because they were made for Beginners on the Flute \& Harpsichord, as that they were composed by a Gentleman who first put a Pencil in my Hand and then an Engraver. But chiefly because they were originally made for your Ladyship's Use which gives me so fair a Handle to send them into the World under the Protection of your Ladyship's Name.

I am with the greatest Respect

Madam,

Your Ladyship's most obedient and most humble Servant, Alexr. Ballle.

Edinburgh

December 1735 . 
insolence and their intemperance. ${ }^{\infty}$ But when Flud, or de Fluctibus, as he called himself, Latinising his name, a distinguished physician and philosopher of the reign of Queen Elizabeth, compares the universe to a pipe into which God breathes life and motion, so exasperated becomes Sir John at the instrument he holds in such contempt being used for this noble figure, that he declares it to be impossible to convey in words an idea of the author's folly and absurdity. ${ }^{70}$

${ }^{89}$ In Hawkins's " History of Music." Preliminary Discourse.

Sir John has taken seriously one of the most absurd tales that ever found its way to the pages of history. Could any sane man be induced to believe that the people of a town seventeen or eighteen miles from London, having invited the College of Organists collectively to a banquet, or individually to their own houses, could so ply them with wine that they could be thrown into wagons, like so many sacks of coal, and carted to London without their knowledge and against their will ?

The high honour in which, as Ovid in his account of the matter testifies, the Roman flute players were held at the time, their dignified conduct in retiring to Tibur instead of brawling in the Temple of Jupiter Capitolinus, or ungraciously refusing their services at a sacrifice, the consideration with which they were treated by the Tiburtines, the anxiety of the Roman Senate to bring about their return, the farewell entertainment given to them at Tibur, the conveyances provided to take them back to Rome at its conclusion, the joy with which they were welcomed by the populace, the restitution of their privileges, and the institution of an annual public ceremony to commemorate their success in resisting the attempted encroachment on their rights, tell a very different tale from that to which Sir John Hawkins has given credence.

Livy, it should be remembered, had no personal knowledge of the incident he related; it took place in the year 309 B.c., three centuries before his time. The chief source from which Roman historians drew their information on the past was the Annals, or official records of public events. The Annals were compiled and kept by the Priests of the Temple of Jupiter Capitolinus, this being the very Temple in which the flute players taking the sacrificial service were deprived of the distinctions conferred on them by Numa Pompilius in recognition of the holiness of their function in relation to the Divine. Attempts, such as are being made at the present time in our Cathedrals to lower the status of the organists, the modern representatives of the Temple flute players, are not of recent origin. Although Appius Claudius was the ostensible agent in the high-handed proceeding, it was the Priests of the Temple of Jupiter who would have been aggrandized, had the attack on the College of Flute players proved successful. What, then, is more natural than that, foiled and mortified, they should, in revenge, have so distorted the facts as to transmit to posterity the materials for the tissue of ridiculous and incredible nonsense repeated, each with his own variations and embellishments, by Livy, Valerius Maximus, Plutarch, Ovid, and Sir John Hawkins?

That flute players were fond of wine in Livy's time is likely enough, for the primitive simplicity of the Roman life had passed away, luxury and dissipation having crept into every class of society. A future Livy of the twenty-second century, desirous of fastening a charge of intemperance on the English violinists of our time, might assert with perfect truth that "as drunk as a fiddler" was a saying in common use amongst us. But, if he were not devoid of a sense of justice, he would be compelled to add that the worship of Bacchus was not confined to those who played the violin, there having been another adage equally well-known, " as drunk as a lord."

70 ." History of Music," Booh XIV . chap civix. 
Sir John's antipathy to the flute would have mattered little had its only effect been to betray him into the use of intemperate language; unfortunately, however, it gave rise to a mental aberration which led him to manifest a want of accuracy at almost every step.

The chief crime laid to the charge of the inoffensive object of Sir John's aversion is that it was "taken to by the fine gentlemen of the time." From Chaucer's Squire downwards the flute seems to have been associated with rank and position. In the frontispieces of the books of instruction I have had occasion to bring forward the flute players represented are evidently men of fashion; but we are not bound to suppose that because they are attired $d$ la mode, they are necessarily fops. It is true that one of them is depicted in the act of practising before a mirror, but this is not an indication of vanity; many modern masters, Boehm amongst them, have recommended their pupils to practise in this way, and it is to be regretted, as the postures of some of our leading flute players too plainly show, that the advice is not more generally followed. Moreover, it should be remembered that when Sir John Hawkins wrote, the harpsichord and the pianoforte (the latter just coming into use) were looked upon as effeminate; he who took up the violin had to run the risk of being stigmatised as a fiddler, not to mention the circumstance that the instrument, even in its elementary stages, was difficult to master; neither the cornet à pistons, the concertina nor the banjo had been invented; whilst the hautboy and the bassoon were more suitable to the orchestra than the drawing-room. Amateurs, then, who wished to take part in music as a recreation, but had no intention of making the art a serious study, or, to use $\mathrm{Sir}$ John Hawkins's words, who "were content to excel only on those instruments on which a moderate degree of proficiency might be attained with little labour and application," had no alternative but to fall back on the flute.

So strong is Sir John's animus against flute players that one cannot help suspecting that he was under the influence of some unknown provocation; that, possibly, he might have been brought into contact from time to time during his literary labours with an offensive flute playing coxcomb, and thus, like Hotspur on the battle-field, being galled

\section{"To be so pester'd with a popinjay,"}

the grave and reverend historian of music so far forgot his dignity as to quote with approval, in connection with flute

"I " History of Music," Bool XVI., chap. cliii.

nsee Fig 23. p. 194 . 
players, the following: "The beaux" of former days "were of quite a different cast from the modern stamp, and had more of the stateliness of the peacock in their mien, than which now seems to be their highest emulation, the pert air of the lapwing." "We daily hear," exclaims the incensed Knight, "of a fine embouchure and a brilliant finger, terms equally nonsensical when applied, as they are, to the German flute"; but in his eagerness to hurl his missile "nonsensical" at the pert lapwing, he overlooks the circumstance that the flute, having, except in the hands of an exceptionally gifted player, comparatively little power of giving accent and modifying sustained notes, relies for its effect on its exceptional flexibility and the unrivalled charm of its tone, so that there is no instrument to which a rapid finger and a good embouchure are of such importance.

After committing himself to the assertion that those who played the flute were less sensible of the charms of melody and harmony than those who made the lute or the viol de gamba the instrument of their choice, and stating that, coming nearer to his own time, the flute was the pocket companion of many who wished to be thought fine gentlemen, and that the use of it was to entertain ladies, and such as had a liking for no better music than a song tune, Sir John informs his readers that from the time when Hotteterre le Romain published his instructions for the German flute, instructions which, he adds, were afterwards improved by Monsieur Corrette in his Method for that instrument, the practice of the flute à bec descended to young apprentices of tradesmen. Sir John states that Hotteterre's work was published about I7ro, a date which has been given as that of Corrette's Method, ${ }^{\text {" }}$ it being said that Hotteterre's Principes de la Flate traversière, as the book was entitled, came out as early as, if not earlier than 1699, Fetis asserting that its title

19 The passage is taken from Colley Cibber's Apology for his Life, p. $2 x_{4}$ of the 4 to edition. The specimen of the stately-peacock-beaux was a gentleman of fortune who had been educated at Oxford, and was occupying chambers in the Temple. He made his way to the Green room of the theatre where Cibber acted, to inquire of him the price of "a fair fullbottom'd Periwig" which he was wearing on the stage. "This singular beginning of our conversation," writes Cibber, "ended in an Agreement to finish our Bargain over a Bottle. . . That single bottle was the sire of many a jolly dozen." The incident here related took place in I695. The stately peacock would seem to have given way to the pert lapwing before 1740, this being the year in which Cibber's "Apology " was published.

"B By Mr. Rockstro in his "Treatise on the Flute," on the authority of Mendel and Reissman. Fétis gives 1788, which is obviously incorrect, for Hawkins's " History," in which the work is mentioned, was published in I776. On the other hand, I7 ro seems to be too early, for Fétis states that in 1780 Corrette held the title of organist to the Duke of Angouleme, so that, if we assume that he was only twenty when his Method was brought out, by 1780 he would have been ninety years of age. 
appears in a catalogue of musical works appended to a, publication issued in that year. ${ }^{78}$

But, be this as it may, although it is true that in the early part of the eighteenth century the German, or lip flute, was supplanting the Common or fipple flute, yet we should certainly be in error were we to believe, drawing an inference from Sir John's words, that by 17 ro the change had gone so far that the use of the fipple flute was confined to the apprentices of tradesmen, as the following will show:-

In 1772 Grano, a professional flautist, who wrote an instruction book for the German flute, was playing solos on the German and the Common flute the same evening. ${ }^{76}$ Of the same date we have the following advertisement: "Richmond Wells will continue open every Day during the Summer Season, by the Proprietors of the last year. There is an extraordinary set of Musick to play Mornings and Evenings; and on Mondays will be a select Band of Musick from the Opera, that perform the most celebrated Opera Songs, accompany'd with the Harpsichord, French Horns, Flutes, and German Flutes." 7 Burney, in enumerating the favourite musicians of 1731 , mentions Jack Festing (Michael Festing's brother) on the German and Baston on the Common flute. In the same year a code of instructions for the instrument appeared in "Prelleur's Music Master" (Fig. 22, p. I93). Indeed, the issue of instruction books did not cease until long afterwards, as can be proved by internal evidence of the books themselves. Thus, Tyther's "Complete Flute Master" (Fig. 24, p. 195) contains a Musette and Minuet from Howard's "Amorous Goddess," which was not composed until 1744, and the "Compleat Instructions for the Common Flute" (Fig. 26, p. 197), King George the Third's Minuet; so that this work must be later than 1760 , the year in which George III. ascended the throne. In $\mathrm{I}_{732}$, as we are informed by Sir John Hawkins himself, Stanesby, the flute maker, in conjunction with Lewis Merci, a flute player well known at the time, were endeavouring to introduce a fipple flute of a new construction, in the hope of arresting the fall of the old favourite. ${ }^{78}$ When Burney was at Florence, in 1770 , he heard a Mr. Hempson, an English gentleman, who, he writes, "plays

76 M. Ernest Thoinan, in his brochure entitled "Les Hotteterre," maintains that the catalogue to which Fétis appeals did not originally form part of the work to which it is attached, and that Les Principes de la Flúte traversière was not published until $1707 \mathrm{He}$ adds that Hotteterre le Romain (whose christian name, it appears, was not Lous, as it is usually given, but Jacques) says himself, in one of his pieces of 1708, that it was in the preceding year that he published his "Traité de flûte."

76 Burney's "History of Music," Vol. IV., p. 647.

77 Chancellor's " Historical Richmond," Appendix, p 266.

78 "History of Music," chap cxxvi., note. 
the common flute in a particular manner, improving the tone very much by inserting a piece of spunge into the mouth piece, through which the wind passes. He performed two or three difficult Concertos, by Hasse, and Nardini, very well."

Nor had the custom of transposing songs for the fipple flute ceased. For instance, "Tamerlane," which was not produced until I724, was published with the following title and preface : "TAMrRlans for the Fluta: an Opera composed by Mr. Handel. Engraved, Printed and sold by J. Cluer in Bow Churchyard, London."

$$
\text { “ Prepace. }
$$

"It having been a constant practice for several years past, to Transpose for the Common Flute all the Opera's which are perform'd upon our Stage, a great many Persons have Complain'd, and still Complain Dayly, of several Faults in the Way hitherto us'd in Transposing; Namely, that the Songs are fitted for the Flute only, and so entirely useless for any other Instrument; thaf very often the highest Notes of the Flute are made use of, which are difficult and uncertain; that in the middle of the Songs little Pieces of the Symphonies are incerted, which causeth often Repititions of the same Passages over and over again; all these things are avoided in this Work, for all, or most of the Songs may be Play'd not only on the Common Flute, but German Flute or Violin; there is not one Song that goes higher than $\mathrm{E}$ above, and all the Symphonies are left out, except those that are absolutely Necessary either to introduce or support the Song, and the Voice Part is preserv'd entire." The work extends to twenty one pages, and contains thirty airs commencing with the overture, without any figured bass or other accompaniment. 70

Sir John does not take leave of the flute without firing a parting shot at the pert lapwings; "the German or traverse flute," he tells his readers, "still retains some degree of estimation among gentlemen, whose ears are not nice enough to inform them that it is never in tune." Here Sir John again

79 Below the "Preface" is the following, which seems to point to the piracies, which Dr. Schclcher has traced to Walsh, of Handel's compositions published by Cluer :

\section{" AdVertisrment.}

"This Day is publish'd, The Favourite Songs in the Opera of TAMRRLANB, in English and Italian. Engrav'd, printed and sold by J. Cluer in Bow Church-Yard. Where may be had the whole Opera of Tambrans in Score, Corrected and Figur'd by Mr. Handel's own Hand; and to render the work more acceptable to Gentlemen and Ladies, every Song is truly translated into English Verse, and the Words engraved to the Musick under the Italian, which was never before attempted in any Opera.

"If J. Cluer's Name is not on the Title Pages of these Works, they are spurious Editions, and not those Corrected and Figur'd by Mr. Handel." 
trips. "The imperfection of the flute," he explains, "consists in the impossibility of attempering its tones, there being no rule or canon by which it can be tuned "; ${ }^{\infty}$ whereas it depended on the circumstance that the instrument was deficient in the number of holes necessary to make the chromatic octave; it was not, therefore, until it got out of the key for which it was pierced that its intonation became so intolerable. This could bave been no secret when Sir John wrote, for Burney, referring to Pronomus, the Greek flute player, who invented a flute on which he could play in three different modes, remarks: "Before his time there was a particular flute for every mode or key, and so out of tune are the majority of modern flutes that it were almost to be wished that the custom had still continued." ${ }^{\text {as }}$ Moreover, before Hawkins's "History" saw the light the reproach had been removed. Although there is some uncertainty as to the precise year in which additional keys were first applied to the onekeyed flute, there can be but little doubt that in 1766 lip flutes with holes for all the semitones, save one, were being manufactured in England.

But there was a Nemesis awaiting Sir John. The instrument which he professed to regard with such disdain proved to be a stumbling-block over which he was destined to fall, and to fall heavily. The failings to which I have called attention are mere trifles and sink into insignificance if compared with his misapprehensions when he treats of the recorder. It is doubtful if the literature of music affords a parallel to the congeries of inaccuracies and misconceptions to be found in the following, which is his account of that instrument: "The flute appears to be an instrument of great antiquity in this kingdom; it is frequently mentioned by Chaucer; and it seems, by the description of it in Mersennus, that there was a species of it, which by himself and other foreigners was termed the English Flute, 'Fistula dulcis seu Anglica.' The proper and most discriminating appellation for it is that of the Flute à bec, or beaked flute; nevertheless we meet with ancient books of instructions for the instrument, wherein it is termed, but very improperly, as it is conceived, the Recorder. Milton could never mean that they were one and the same instrument, when in the same line he mentions

'Flutes and soft Recorders.'

"Among bird-fanciers the word record is used as a verb to signify the first essays of a bird in singing; and it is well known that Bullfinches and other birds are taught to sing by a flajolet. Lord Bacon in his Natural History, Cent. III. Sect. 22I, speaks of Recorders and Flutes at the same instant,

60 "History of Music." Preliminary Discourse. Note.

81 Burney, "History of Music," Vol. I., chap. iv. 
and says that the Recorder hath a less bore and a greater, above and below; and elsewhere, Cent. II. Sect. 187, he speaks of it as having six holes, in which respect it answers to the Tibia minor or flajolet of Mersennus. From all which particulars it should seem that the Flute and the Recorder were different instruments, and that the latter in propriety of speech was no other than the flajolet.

"Nevertheless the terms are confounded; and in a book of instructions and lessons for the flute, so old that the notation is by dots, the instructions for the instrument are entitled directions for the Recorder."

In examining this extraordinary accumulation of errors, one scarcely knows where to begin. Perhaps, however, that which has been most potent in leading later writers astray is the statement in which Sir John conveys the impression that Bacon described the recorder as a six-holed instrument. Turn where we will, we find the effect of what Sir John has written. So enduring is the mischief it has wrought, that although nearly a century and a quarter have elapsed since Sir John Hawkins's " History of Music" appeared, yet in an otherwise admirable and charming little book, written only a year or two ago by a member of our Association, we are told that Bacon says that the recorder had six holes, and that the six holes may be seen on any penny whistle.

It is, of course, almost needless to say that we look in vain for such an assertion in Bacon. What we do find is a sentence in which Bacon refers to "the first three" and to "the three uppermost" holes of the recorder. It was by adding these two threes together that Sir John arrived at the number six; it seems never to have occurred to him that a recorder might have other holes besides " the first three" and " the three uppermost." Moreover, owing to the difficulty of ascertaining Bacon's meaning, we are unable to identify the holes named; so that, if it should be that "the three uppermost " are included in " the first three," only four holes would be mentioned. Dr. Stone, when writing for Grove's " Dictionary," not being able to understand the sentence, ingeniously laid the blame on Lord Bacon, declaring that the "paragraph begets a suspicion that the learned writer was not practically acquainted with the method of playing this instrument." There is a passage in the "Sylva Sylvarum" from which it may be inferred that Dr. Stone's suspicion was not well founded; but there can be no doubt about the obscurity of Bacon's paragraph, which is as follows:- "There is required some sensible difference in the proportion of creating a note, towards the sound itself, which is the passive; and that it be

". . . in pipes, and the like, the lower the note holes be, and the farther of from the mouth of the pipe, the more base the sound they yield, and the nearer the mouth, the more treble."-Century II., section 178. 
not too near, but at a distance. For, in a recorder, the three uppermost holes yield one tone, which is a note lower than the tone of the first three. And the like, no doubt, is required in the winding or stopping of strings."

Strange as is Sir John's oversight respecting the number of the holes of the recorder, his assumption that Bacon used the word flute to denote the English, Common, or Fipple flute, or, as Sir John wished it to be called, the flute a bec, is scarcely more excusable; for before his eyes in the very work from which he was quoting, the "Sylva Sylvarum," or "Natural History," there was a passage in which Lord Bacon had indicated in the clearest and plainest language a man could use that by the word flute he meant the very same instrument, the German, transverse, or lip flute, to which we now apply the term. "But then you must note," he writes, "that in recorders which go with a gentle breath, the concave of the pipe, were it not for the fipple which straitneth the air, much more than the simple concave, would yield no sound. . . . And note again that some kind of wind instruments are blown at a small hole in the side, which straitneth the breath at the first entrance; the rather in respect of their traverse and stop above the hole, which performeth the fipple's part; as is seen in flutes and fifes which will not give sound by a blast at the end, as recorders, \&c., do."

But the most amazing of all Sir John's self-deceptions is his delusion that books of instruction entitled for one instrument were really intended for another. How any man in his sober senses, much less one who aspired to write a History of Music, could entertain such a belief seems, at first sight, to pass all understanding. That Sir John's conviction that books of instruction, stated to be for the recorder, were really intended for the flute, did not open his eyes to the fact that the flute and the recorder were the same instrument is, however, to be ascribed to the almost inconceivable influence of a power against which we can never be too much on our guard: a power which tempts us, as we shall see when we come to Mr. Chappell, to distort passages and to alter expressions in order to make them correspond with our ideas, the power of preconceived opinion. It was not only on Sir John Hawkins and Mr. Chappell that this power made itself felt. No writer on the recorder has brought greater learning or more research to bear on his subject than Mr. Douce. Although Mr. Douce has the sagacity to perceive that Sir John's belief that the books of instruction were not intended for the instrument for

6 It has been said that Lord Bacon, although he was the founder of the inductive method, showed himself to be but an indifferent scientist when he proceeded to put his system into practice. His observing power is certainly here at fault: for it is neither the mouth-hole nor the "traverse or stop" of the lip flute which performs the fipple's part in straightening the air, but the lips of the performer. 
which they were entitled "seems," to use his polite phrase, "rather doubtful," yet, so entirely are our reasoning powers under the dominion of prejudice, that, having accepted the view that the flute and the recorder were different, he brings forward in support of his opinion arguments which really tell against it. The following is an extract from his remarks on the recorder in his able and interesting work entitled "Illus. trations of Shakespeare":-

"Recorders-i.e., says Mr. Steevens, a kind of large flute. Yet the former note to which he refers, Vol. V., p. 149, describes the instrument as a small flute. Sir J. Hawkins in Vol. IV., p. 479, of his valuable History of Music has offered very good proofs that the recorder was a flagelet, and he maintains that the flute was improperly termed a recorder, and that the expressions have been confounded; yet his opinion that the books of instructions entitled 'for the recorder' belong in reality to the flute, seems rather doubtful. - . . In Udall's Flouers for Latine Spekyng selected out of Terence, $1532,12 \mathrm{mo}$, the line from Virgil's Bucolics,

$\mathrm{Nec}$ te poniteat calano trivisse labellum,

is rendered, 'and thinke it not a smalle thinge to have lerned to playe on the pype or the recorder': and it is not a little curious that in modern cant language the recorders of corporations are termed fiutes. The following story in Wits Fits and Fancies, 1595, 4to, shows that the pipe and the recorder were different; such is the uncertainty of definition among old writers : A merrie recorder of London mistaking the name of one Pepper, call'd him Piper: whereunto the partie excepting, and saying: Sir, you mistake, my name is Pepper, not Piper; hee answered: why, what difference is there (I pray thee) between Piper in Latin and Pepper in English; is it not all one? No, Sir, (reply'd the other) there is even as much difference betweene them, as is between a pipe and a recorder."

Now, had Mr. Douce not allowed his judgment to be warped, he would have perceived that Pepper's very smart rejoinder, instead of proving that the pipe and the recorder were different, proves, if it proves anything at all (which it does not), that they were one and the same. "It is true," says Pepper, in effect, "that piper in Latin and pepper in English are all one; but it is also true that a pipe and a recorder are all one; nevertheless, you, though a Recorder, are not a pipe, nor am I, though Pepper, piper."

To reply further to Sir John's arguments would be a work of supererogation; I shall content myself with a proof of the identity of Sir John's flute, with his recorder, taken out of Sir John's own book. To show "that the flute was formerly the instrument of a gentleman," after appealing to "that graphical species of representation called still life," Sir John goes on to say, "but if this particular fail to prove that the 
flute was the recreation of gentlemen, what shall be said to a portrait of one of our poets, who died above fifty years ago, drawn when he was about twenty, wherein he is represented in a full trimmed blue suit, with scarlet stockings, rolled above his knees, and playing on a flute near half an ell in length; or to this" (Fig. 27), "which is the frontispiece to a book of instructions and lessons for this instrument, published about the year I $700 . "$

Now a comparison of Sir John's figure with the engraving in "The Genteel Companion" (Fig. 16, p. 184) shows that in $168_{3}$, seventeen years before he appeared in the book of instructions for the flute, Sir John's fine gentleman was doing duty as frontispiece to Salter's "Exact Directions for the

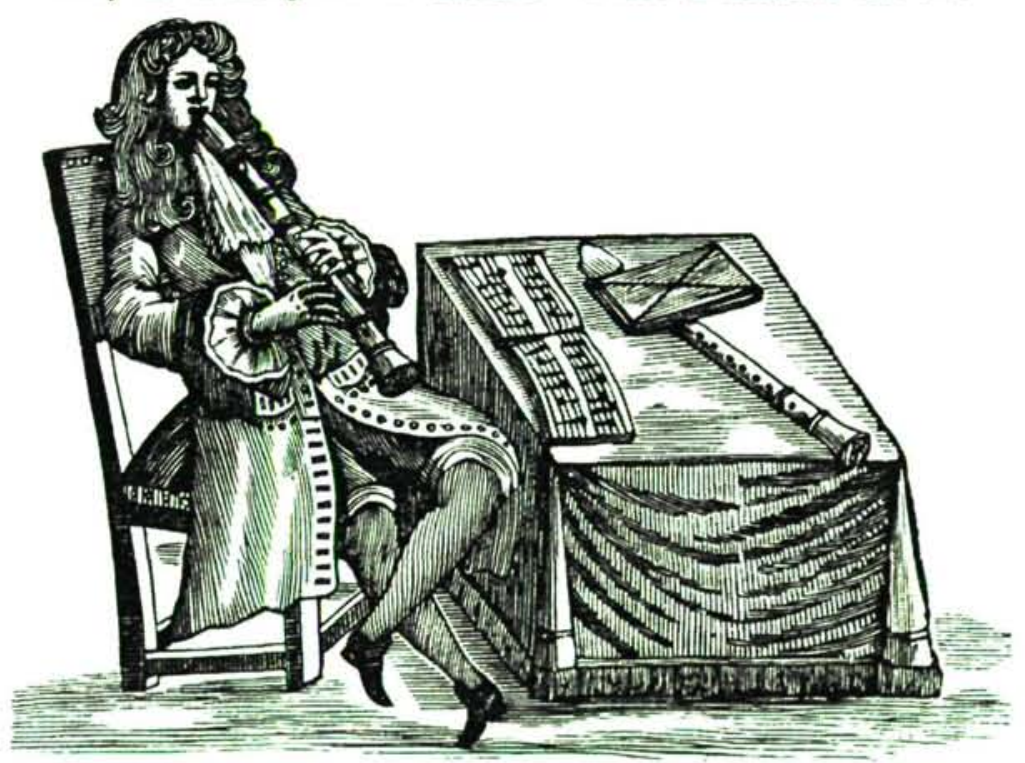

FIG. 27.

Recorder." It is true that by I 700 the lady, whom I have supposed to be his wife, had disappeared, but the fine gentleman is still sitting on the same chair, with his legs still crossed, is wearing the same periwig, the same coat, the same breeches, the same stockings, the same shoes, is playing on the same instrument, and even fingering the same note.

A seeker for information on the subject of the recorder, who felt dissatisfied with Hawkins's account of the instrument, would naturally bethink him of Burney. Hawkins and Burney were rival historians. Sir John was a man of sterling worth, but he was so harsh and bearish that Doctor Johnson, though 
he appointed him his executor, declared him to be unclubable; Burney, on the other hand, was the embodiment of urbanity and politeness. Moreover, Sir John was not within the charmed circle of the musical profession, whilst he and Burney wrote at a time when the jealousy with which outsiders were looked upon was far greater than it is at present. The feeling with which Hawkins was regarded by the partizans of Burney is well shown in Callcott's once popular catch, where he is treated contemptuously in the words when taken by themselves, but is more than ridiculed when the catch is sung, the music being so contrived that the singers seem to say to each other :

Sir John Hawkins :

Burn his History :

How do you like him?

Burn his History.

The whole of Hawkins's five volumes were published in 1766 , but only the first of Burney's four came out in that year; the remaining three were issued at intervals, the third, which contained the notice of the recorder, not appearing until 1789 , thirteen years afterwards. The inquirer would therefore naturally argue that, if Hawkins was mistaken, Burney could be relied on to point out the error. But, on turning to Burney, what would he find ? Nothing less than a direct and unqualified confirmation of the opinion expressed by Hawkins: "a recorder," he writes, "is a flageolet, or bird pipe."

How is this to be accounted for? The answer is, unhappily, only too simple; Burney availed himself of Sir John's labours, but omitted to acknowledge his obligation. I am not the first to make this discovery; Burney was detected long ago by Mr. William Chappell, and detected in precisely the same way, through him having followed Sir John into his mistakes. "He copied," writes Mr. Chappell, "especially from Hawkins, without acknowledgment, and disguised the plagiarism by altering the language. Many of his appropriations are to be traced by errors which it would be impossible that two men reading independently could commit." mately acquainted with Sir John Hawkins's grandson, Colonel Hawkins, and that I have had more than one conversation with him on the subject of the relations of Dr. Burney with his grandfather, Sir John. I have thus been favoured with a glimpse behind the scenes; but what was then revealed it is neither necessary nor desirable that I should disclose.

For nearly a century after the publication of Sir John Hawkins's "History of Music" no further attempt was made to unriddle the mystery of the recorder. A bout the year 1859 ,

as Burney's " History of Music." Vol III., p. 336.

so Chappell's "Popular Music of the Olden Time." Introduction, p. ix. 
however, there appeared a work in which an entirely new view of what constituted a recorder was given to the world. The book to which I refer was Mr. William Chappell's "Music of the Olden Time." But before discussing Mr. Chappell's ideas, it is desirable that I should say a few words about a so-called flute with which, possibly, some present may be but slightly acquainted.

When the vibrations which produce a musical note are allowed to impinge on a thin membrane stretched sufficiently tight to be capable of being thrown into vibration, the membrane proceeds to vibrate and to give out a note of its own. The note, thus generated, is of the same pitch as the first note, but differs from it in timbre. If the new note with its altered timbre mingles with the old note, it seems to the ear that the old note has undergone a change of quality. It was once proposed to take advantage of this circumstance with a view of removing some of the harshness by which, owing to the illiberality of Dame Nature in her vocal gifts to mankind, the majority of human voices are marred. Lord Bacon observed that if the voice was projected into the hole of a drum, it seemed to become sweeter, and he suggested that recourse should be had to this expedient in order to make the voices of those engaged in part-singing more agreeable to the ear; but as a number of vocalists, each singing into the hole of a drum, would not be a very dignified spectacle, he made the wise proposal that the singers with their drums should be concealed from the audience. "If you sing into the hole of a drum," he writes, " it maketh the singing more sweet. And so I conceive it would, if it were a song in parts sung into several drums; and for handsomeness and strangeness sake, it would not be amiss to have a curtain between the place where the drums are and the hearers."

The want of "handsomeness," to which Bacon alludes, was obviated by the construction of a special instrument. It consisted of a tube (Fig. 28, A, c), terminating at one end in an open bell mouth (c), but closed at the other by a piece of thin parchment $(A)$, stretched like the head of a drum, and covered, for protection, with a movable cap perforated with holes $(A, B)$. In the side of the tube, not far from the mem. brane, was a hole (B) into which the performer directed his voice. The instrument was called the Eunuch Flute. Whether it was so termed on account of it not being able to generate sound, or because it emasculated the voice of the singer by imparting to it, as it did, an œgophonous or bleating character, or for some other reason, I am unable to say. Mersenne, who describes and figures it, states that

00 There is no date on the title-page of this work, but from the stamp impressed on the copy in the Reading Room of the British Museum, it appears that it was received in 1859 . 


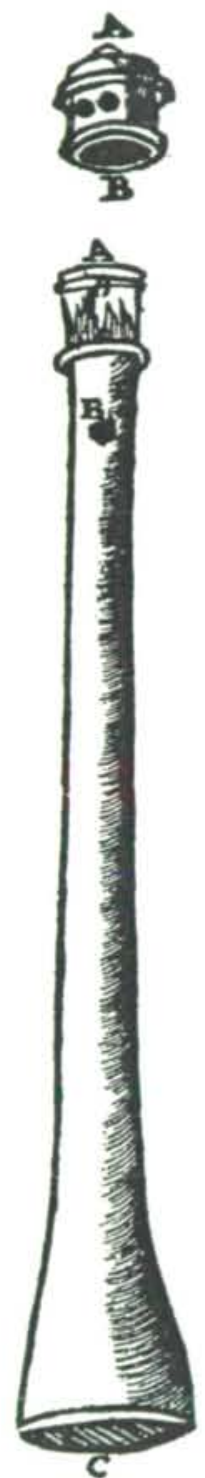

Fig. 28.-EUnUCh Flute, rrom Mersenne. 
music in four or five parts was performed on such instruments; the Eunuch Flute having "the advantage over all other flutes that it imitates better the concert of voices, for it lacks only the pronunciation to which a very near approach is made on these flutes." "The little drum," he adds, " imparts a new charm to the voice by its tiny vibrations which reflect it." This circumstance Mersenne, ever ready with a practical suggestion, goes on to say, "should be carefully noted by organists and organ builders with a view of inventing new stops which should imitate human voices much better than their Regals, and so beguile the auditors they should believe that they are listening to a better concert than that of voices which lack the softness of the harmony and of the charms of the pieces of membrane which can be introduced in divers places in organ pipes and flutes."

The Eunuch flute is not yet extinct ; it is still manufactured for the delectation of children, both in England and the United States; but, like the recorder, it has undergone a change of name. I have one here, kindly lent me by the maker, $\mathrm{Mr}$. Barr, of Bow Lane. He calls it the Zazah, or Voice Flute. ${ }^{88}$ It is constructed like that figured by Mersenne, except that three finger-holes have been pierced in the tube. It will, of course, be understood that the finger-holes do not affect the intonation; but it is stated that by stopping two of them, and shaking the finger on the third, the effect of a tremolo can be produced. A peculiarity of the Eunuch Flute noticed by Mersenne is that it augments the sound of the voice, the note given out being louder than that by which it is produced, as you will hear if I hum into the instrument.

In India the principle of the Eunuch Flute has attained a singular development. There is in use there an instrument called the Nyâstaranga. It is formed of a metal tube, in shape somewhat resembling a speaking trumpet. At its upper end

87 Mersenne, "Harmonie Universelle," Lib. V., Prop iv.

When treating of the organ Mersenne returns to the subject: "I pass over other inventions," he writes, "by which organ builders could enrich the stops of the organ: for instance, if little pieces of sheeps' skin, peeled as thin as that of onions, are placed at the end of pipes to stop them, or if sundry holes are 'made in the body of the pipe which should be stopped by the aforesaid skin, there will be heard a singular harmony which can be still further varied by the difference in the movements which are given to the wind."

${ }_{88}$ The following letter, addressed to Mr. Barr, will give an idea of the sort of use ta which the Eunuch flute is now put :-

"Mrs. Gladstone's Orphanage, Hawarden.

"Dear Sir,-I received the goods (Drum and $\mathrm{Za-Zah} \mathrm{Band)} \mathrm{on} \mathrm{the} \mathrm{Irth}$ inst. The boys had them out the same night and started to play directly. I was quite surprised. indeed, how well they played; it made quite a sensation. On Saturday last the boys had the honour of playing the $\mathrm{Za}-\mathrm{Zah}$ before the Right Hon W. E. Gladstone and Mrs Gladstone and family. who pronounced them excellent. They gave the boys tos to buy a contra Bass.-ANDREW WILIIAMS." 

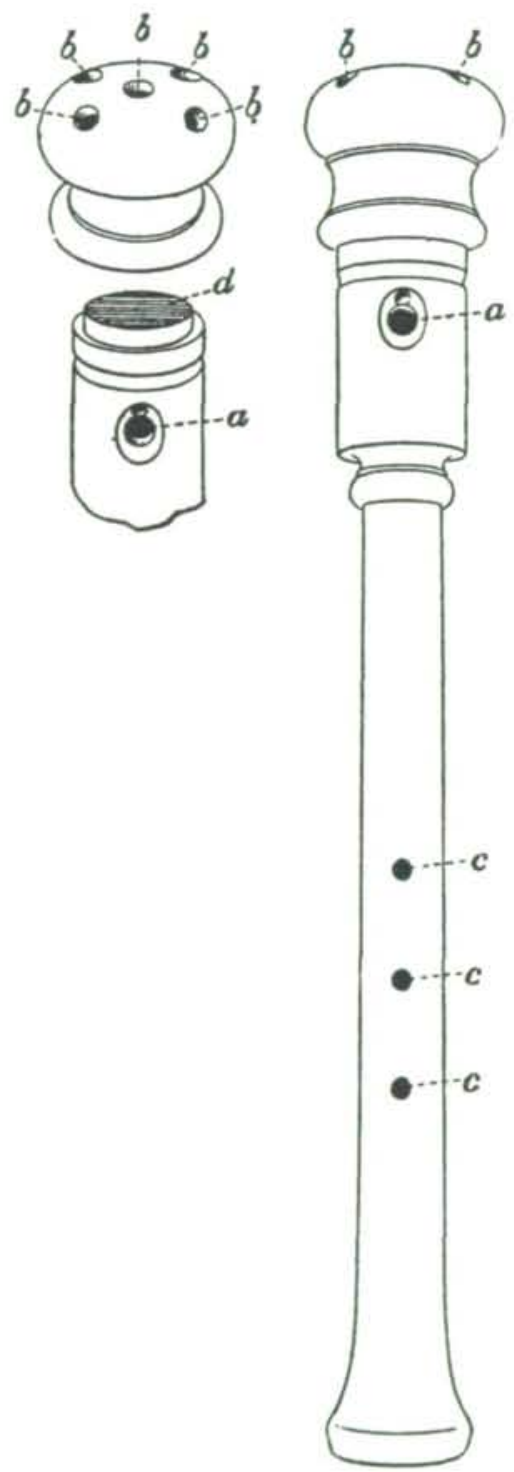

Fig. 29.-Modern Eunuch Flute.

a. Hole into which the poice is projected; $b$. holes in cap; $c$. finger-boles; $d$. vibrating membrane. 
it terminates in a shallow cup. A small hole at the bottom of the cup opens into the tube, the hole being covered with vibratile membrane. The performer applies the cup to the side of his neck, in the region of the larynx. The vibrations of

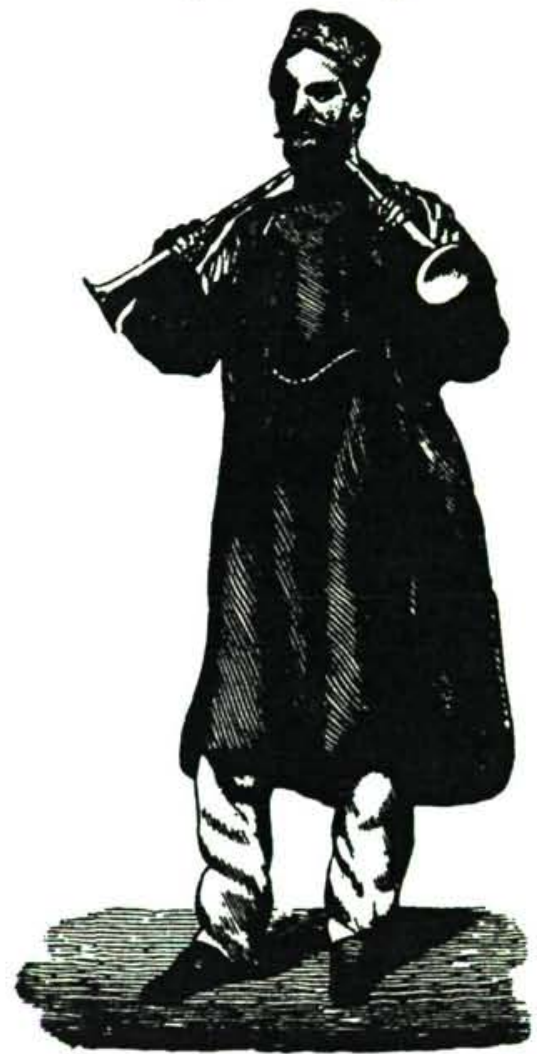

FIG. 30.-NYAstARANGA-PLAYER.

the voice, propagated through the cartilages of the larynx, and the other intervening tissues are taken up by the air in the cup, which, in its turn, communicates them to the membrane, and thus the instrument is made to sound. ${ }^{\infty}$ A more common

* An account of the Nyastaranga is given in M. Victor Mahillon's "Catalogue Descriptif et Analytique du Musée Instrumental du Conservatoire Royal de Musique de Bruxelles." 1 am indebted to the kindness of M. Mahilion for the illustration. As the account given of the way in which this extraordinary instrument is played is sometimes received with incredulity, I think it right to add that I have heard the Nydstaranga sounded; Mr. Henry Balfour, the Curator of the Ethnographical Department of the University Museum at Oxford, can make it speak. It imparts to both the singing and the speaking voice the weird effect of the phonograph. 

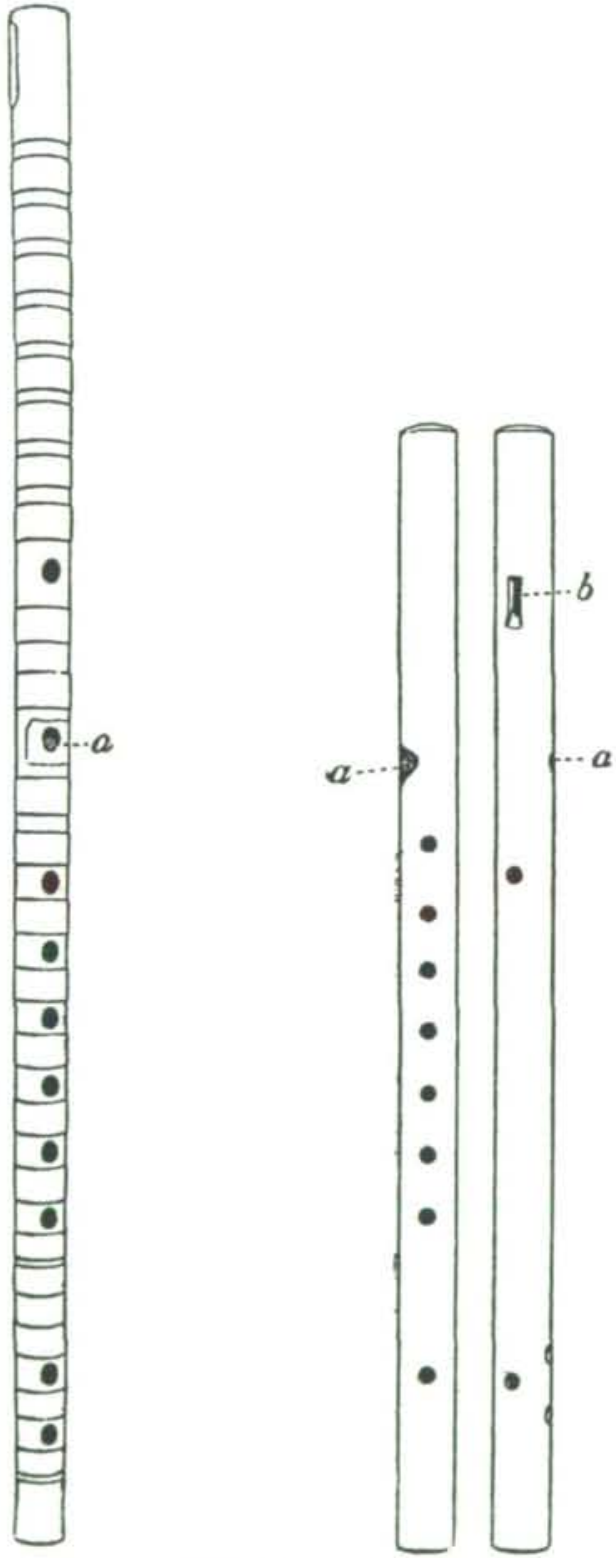

Fig. 31.-Chinese Ti-TZU, shown in Fig. 32.-Siamese Ki.U1, Back the LOAN COLlection OF 1885 . AND FRONT VIEW

a. Hole covered with membrane, or paper. a. Hole covered with tissue paper ; $b$. mouth. 
use, however, to which this principle is put in the East is to cover holes, bored in the tubes of flutes, with a vibrating lamina. Here are drawings of a Chinese lip flute and of a Siamese fipple flute, on each of which a hole so covered appears ${ }^{\text {po }}$ Figs. 3 I and 32).

Now, Mr. Chappell was of opinion not only that a recorder was provided with a similar hole covered with membrane, but that this hole was termed the recorder; and that it was from the hole, thus called, that the instrument itself derived its name. After referring his readers to Salter's "Genteel Com. panion," he expresses himself thus :-

"Recorders and (English) Flutes are to outward appearance the same, although Lord Bacon in his Natural History, cent. iij., sec 22 I, says the Recorder hath a less bore, and a greater above and below. The number of holes for the fingers is the same, and the scale, the compass, and the manner of playing, the same. Salter describes the recorder from which the instrument derives its name, as situate in the upper part of it, i.e., between the hole below the mouth and the highest hole for the finger. He says, 'Of all the kinds of music, vocal has always had the preference in esteem, and in consequence, the Recorder, as approaching nearest to the sweet delightfulness of the voice, ought to have the first place in opinion, as we see by the universal use of it confirmed.' The hautboy is considered now to approach most nearly to the human voice, and Mr. Ward, the military instrument manufacturer, informs me that he has seen 'old English Flutes' with a hole bored through the side, in the upper part of the instrument, the holes being covered with a thin piece of skin, like gold-beater's skin. I suppose this would give somewhat the effect of the quill or reed in the Hautboy, and that these were Recorders. In the proverbs at Leckingfield (quoted ante, Note $b, \mathrm{p} .35$ ) the Recorder is described as 'desiring' the mean part, but manifold fingering and stops bringeth high (notes) from its clear tones. This agrees with Salter's book. He tells us the high notes are produced by placing the thumb ${ }^{91}$ half over the hole at

00 The Siamese flutes were made of ivcry. They belonged to a flute player in the King of Siam's band, which gave a series of performances in the Albert Hall during the Inventions Exhibition of 1885 , who kindly allowed me to have them photographed. It will be observed that the mouth, instead of being in the front of the instrument in a line with the finger-holes, as in European fipple flutes, is placed with the thumb-hole at the back.

On The highest hole of the recorder, that closed with the thumb, served a double purpose-to emit a note of its own and to act, when required, as a vent hole, or speaker, for the production of upper notes. When it was used for the latter purpose it was necessary to reduce its size. This was done by turning up the thumb, as if the player intended to pinch the instrument. From this circumstance the notes so produced were termed the "pinched notes." In flutes which have been much used the thumb.hole usually shows traces of an indentation causerl by the nail The following is from Salter - 
the back and blowing a little stronger. Recorders were used for teaching birds to pipe." 92

When we reason from notions to facts, instead of from facts to notions, we run the risk, as I have already said, of only seeing in the facts a confirmation of our notions, and expose ourselves to the danger of being led to manipulate the facts in order to bring them into harmony with what we believe to be their true explanation. Passing over, then, two questions, one, whether the hautboy or the flute more nearly resembles the human voice, the other, if the recorder was or was not used to teach birds to pipe, there are no less than three statements in Mr. Chappell's account of the recorder to which I shall have occasion to take exception.

First, as regards Mr. Chappell's allusion to the Leckingfield proverb relating to the recorder, I have already pointed out ${ }^{93}$ that no such passage as " bringeth high (notes) from its clear tones " is to be found in the original.

Secondly, Mr. Chappell would have us believe that Lord Bacon states that the recorder "hath a less bore, and a greater above and below," than the English flute. But in the passage to which Mr. Chappell refers, Bacon is drawing attention to the circumstance that although transverse flutes and recorders resembled each other in being straight, they differed in the shape of the bore. In Bacon's time the bore of the transverse or German flute was cylindrical, that of the recorder being conical, or, to use Bacon's quaint phrase, the recorder had "a less bore and a greater, above and below." His words are, "The figures of recorders, and flutes, and pipes are straight; but the recorder hath a less bore and a greater, above 24 and below." Mr. Chappell, however, has not only introduced in a parenthesis the word "English" before "flutes," 25 but has changed the punctuation by removing the comma from after the word "greater," where Bacon placed it, and inserting it after the word " bore"; thus giving to the passage a meaning quite different to that intended by Bacon.

Thirdly, Mr. Chappell writes: "Salter describes the recorder from which the instrument derives its name, as situate in the upper part of it, i.e. between the hole below the mouth and the highest hole for the finger." Now a careful perusal of

"Your pinching Notes ascend higher than the plain Notes . . . to play these on the Kecorder, you must bend your left Thumb, and let it be half over the hole underneath the Pipe. . . and pinch the Nail of your Thumb in the hole, then blow your Recorder a little stronger than you did when you played the other Notes and you shall find the Recorder sound eight notes."-C. $W$.

92 "Music of the Olden Time," p. 246, note $a$.

Susra, p. I 52 .

21 "Natural History," Century II., section 221.

26 That Bacon used the word "flute" to denote the German or transverse flute has been already shown (supra, p. 206). 
Salter's book fails to reveal the existence of the slightest allusion to such a hole. How, then, could Mr. Chappell have brought himself to this belief? I can only suppose that it might possibly have been through the following misconception.

In referring to the finger-holes of the flute, we often call the hole which comes nearer to the bottom or open end of the instrument the lowest hole, and we speak of the hole next to it as being above that hole, and so on of the other holes as being above one another, until we come to the hole nearest to the mouth, a hole which, being the uppermost, is also denominated the first hole. On the recorder this first, or uppermost hole, being stopped with the thumb, was pierced on the side of the tube opposite to that on which the other finger-holes were placed, so that it was underneath the recorder when the instrument was held up for playing. Now Salter writes: "The first hole is, that underneath which you must stop with your Thumb . . . ; the second hole is next to that above" (i.e., on the upper aspect of) "the Recorder, and you are to stop that with your first finger." I imagine, then, that perhaps Mr. Chappell may have interpreted the expression "above the Recorder" to mean "nearer to the mouth than (something called) the recorder"; an interpretation to which the absence of a comma before "above" (Salter's acquaintance with the art of pointing being of the slightest) would contribute not a little. What could the recorder be? That it was the hole covered with thin skin, of which he was in search, was an answer which Mr. Chappell would naturally return to himself. It would follow, as a matter of course, that the hole, thus called, gave its name to the instrument.

We now come to the information given to Mr. Chappell by Mr. Cornelius Ward-viz., that he had seen a hole covered with membrane in old flutes. It is only right to say that I have had occasion to examine Mr. Ward's evidence in another case, and that I there found him to be the reverse of a satisfactory ${ }^{*}$ witness; nevertheless, we need not consider ourselves bound to reject his statement as unfounded, although the negative evidence opposed to it seems so overwhelming. Mersenne informs us that such holes could be introduced in flutes; ${ }^{97}$ we may, therefore, conclude that the experiment had been tried, and we may suppose that it might have been repeated from time to time; moreover, it is not impossible that Mr. Ward may have seen the instrument $I$ am about to describe.

We are told, then, in Grove's Dictionary (Art., "Recorder") that there was shown in a Loan Collection of Musical Instruments at South Kensington, an English Recorder of the seventeenth century, and further that this recorder was

- See the writer's "History of the Bahm Flute," third edition, p. 186, also note 44, p. 467 , in the same work.

97 " Harmonie Universelle," loc. cit., supra, p. 212. 


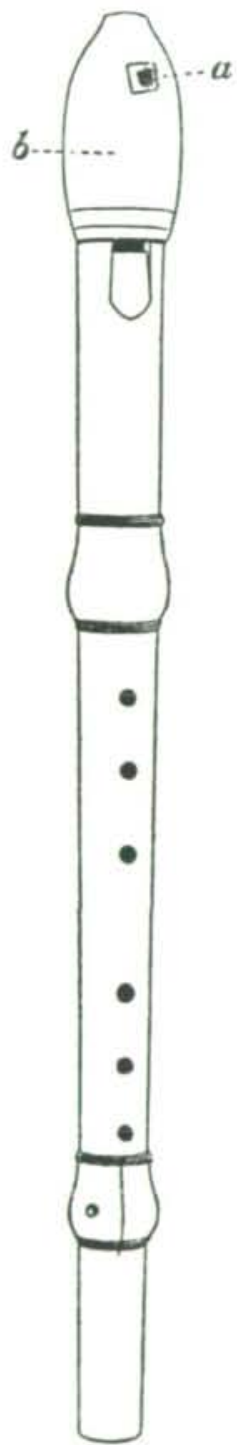

Fig. 33.-Fipple Flute in the South Kensincton Museum. a. Hole covered with thin skin: $b$, movable cap. 
furnished with a hole covered with thin bladder. That there is to be seen in the South Kensington Museum (the instrument is still there, it having been purchased at Carl Engel's sale) a fipple flute in which a special hole has been bored, and that this hole is covered with membrane, is undeniable; but I shall have no difficulty in showing not only that the hole, thus covered, neither does, nor ever did, affect the quality of its tone, but that the reputed recorder of the seventeenth was really made in the nineteenth century, Carl Engel, to whom the statements can be traced, ${ }^{\text {p9 }}$ having been mistaken.

The instrument is of boxwood, stained of a dark colour. Its total length is $2 \mathrm{ft}$. $1 \frac{7}{8} \mathrm{in}$. It measures $\mathrm{I} \mathrm{ft}$. $9 \frac{5}{8} \mathrm{in}$. from the mouth to the lower end. It is constructed in three separate pieces or joints; the finger-holes (the state of which shows that it has been but little used) are of the usual number, eight, and are arranged in the ordinary manner with the thumbhole at the back; in short, the instrument presents the characteristics of a Common Flute of the very latest type.

Now for its peculiarities. The observer is at once struck with the circumstance that it has no beak, but terminates at its upper end in a movable cap (Fig. $33 b$ ), somewhat resembling a pear in shape, but truncated above. At the apex is the hole into which the player impels his breath. The wind, after passing through the hole, enters a circular chamber, an inch in diameter, having a flat roof. Below the chamber of the floor of which it forms the chief part, is the fipple. It is made of cedar, a wood often employed for the purpose in well-finished flutes. The floor of the chamber is cut away at the back, so that the chamber is deeper behind than before; its depth being $\frac{1}{18}$ in. behind, but only $\frac{9}{16}$ in. in front. Through the wall of the chamber, close to the roof, there has been pierced a hole in. in diameter (Fig. 33 a), the hole being covered with a film of gold-beater's skin or some similar delicate membrane.

As the hole does not open into the tube where the column of air is in vibration, but into the chamber above the fipple, it is obvious that the vibrating column of air is not brought into contact with the membrane. Even if we were to suppose that the vibrations could be conveyed to the membrane by the material of the instrument, they would reach it in a direction parallel, not at right angles, to its surface. It is not possible, therefore, that they could, either directly or indirectly, cause it to vibrate.

For what purpose, then, was the hole designed? In considering how to give an answer to this question, it seemed to me that the only sound which could act on the membrane would be that of the voice of him who played the instrument.

\footnotetext{
os Engel's "Catalogue of the Instruments in the South Kensington Museum," p. 372.
} 
I was thus led to conjecture that an attempt had here been made to combine a Eunuch with a Fipple flute, so that the performer should sing into the instrument, and thus set the membrane vibrating, whilst he played the flute in the usual way with his breath and fingers. ${ }^{\boxplus 9}$ Whether this was, or was not, the intention of the maker, I will not pretend to say; but on the instrument having been kindly placed at my disposal by Mr. Skinner, I proceeded to sound it, but did not, of course, produce any effect on the membrane. No sooner, however, did I hum softly into the mouth-hole than the membrane sent forth a note so loud as not only to drown the sound of my voice, but to attract the attention of a member of the staff of the South Kensington Museum, Mr. Mitchell, who was in the room at the time.

Next as to its date. It happens that each of the three jointsthe head, the middle, and the foot-bears the maker's name, Goulding and Co. On one of them the address also is given; but, owing to the inscription having been partially obliterated, seemingly with a hot-iron, all that can be deciphered is-

\section{GOULDING \& CO., NEW}

\section{LONDON.}

It is easy to supply what is missing. It was in New Bond Street that Goulding \& Co. carried on business. They moved thither from Pall Mall and St. James Street in 1803 or 1804 , and remained there until I8I I, when they left for Soho Square. We can therefore say with certainty that the instrument was made between 1802 and 1812 , whilst probability points to 1809 or 1810 as its precise date; for it was only during those two years that the firm was styled George Goulding \& Co. From 1803 to 1806 , it was named Goulding, Phipps and D'Almaine; in 1807 and 1808 , Goulding, Phipps \& Co.; and in $18 \mathrm{rr}$, Goulding, D'Almaine \& Co.

Having now accomplished my task of showing that neither Sir John Hawkins, Dr. Burney, nor Mr. William Chappell had a correct perception as to the instrument to which the name recorder was applied, I will say no more, pleading in excuse for so abrupt a conclusion the unconscionable length to which this paper has already grown. In my unenviable duty of drawing attention to the shortcomings of distinguished men, I should be vain indeed were I to believe that I have myself escaped the toils of error. May I be allowed to hope that, before we disperse, statements to which objection can be taken will be pointed out, lest they go forth unchallenged to the world?

99 There is nothing new in the idea of a person humming notes with his voice whilst playing the fipple flute. Mersenne in his description of the finte donce says that a performer can sing the bass whilst he plays the air, "so that one man can make a duett." 


\section{DISCUSSION.}

Tue Chairman.-Ladies and Gentlemen, if you feel as I do, you are extremely grateful to our kind friend, Mr. Welch, for the information on a subject upon which, I believe, very little is known. He seems to have solved the question of the use of the membrane covering the hole of the Recorder, and I am sure his paper when printed will be of very great value. There are one or two points in his paper which suggest a few remarks, first of all about Hawkins' history. If I had dreamt that the matter would have cropped up to-day I would have brought with me a manuscript book which states distinctly who wrote Hawkins' history for him. He employed Dr. Benjamin Cooke, Dr. William Boyce-Overend, of Isleworth, and John Stafford Smith. I think the musicians prepared the musical pearls and Hawkins strung them together: I mention this, feeling interested in the duel between Hawkins and Burney. I am not prepared to attempt to prove that the voice would be improved by singing into a drum; it might make more noise, but not more music. Regals were little portable harmoniums or organs. The teaching of birds to sing has been referred to. I have here a book undated. It is called "The bird fanciers' delight, or choice observations and directions concerning the teaching of all sorts of singing birds, after the flageolet and flute (when rightly made as to size and tone), with lessons properly composed within the compass and faculty of each bird-canary, linnet, bullfinch, woodlark, blackbird, throustill, nightingale, and starling." On the title-page there are representations of birds and also a Recorder. It prints the tunes the birds were supposed to sing. They are extraordinary and quite worth looking at. Then I have another book for the flageolet, with lessons and instructions by Thomas Greeting. The preface is amusing; it describes the flageolet as "a pleasant companion having the advantage of being always in tune, and for those whose genius leads them to music no more pleasant instrument." I for one feel deeply indebted to the lecturer who has given us such an admirable lecture, and I am sure it will be valuable for perusal and reference, and I therefore propose a hearty vote of thanks to $\mathrm{Mr}$. Welch for preparing the paper. I am sorry to see so few here, but those who are absent know that they can study the paper at their own homes.

The motion was carried unanimously.

Mr. Southate.-I was in hopes that Mr. Welch would have told us something more about the nose flutes used in Polynesia and some parts of India. I once asked a gentleman 
who had some acquaintance with the South Sea Islands if he could tell me anything about the use of these curious instruments, and he said it was considered impure if anything which had touched a person's mouth should also touch another's; but this did not apply to the nose. Consequently, those blown through the nostril and not the lips permitted any person to take up and play them without defilement. ${ }^{100}$ I believe that an inventory of Henry VIII.'s musical instruments will be found in Rimbault's " History of the Pianoforte." I recollect that at the grand meeting presided over by the Prince of Wales, on the formation of the Royal College of Music, Lord Rosebery made some remarks on this monarch playing the harpsichord. He was wrong; the king may have played the virginal and the clavichord, the harpsichord was not then invented; he certainly played the Recorder and also the Regal. I think in the book of "Household Expenses of Henry," edited by Sir Nicholas Harris, some account will be found of these instruments which contributed to His Majesty's "Diversions." With regard to the membrane mentioned, may I tell you that many of the Chinese flutes of to-day possess these membranes pasted over a hole in the body of the instrument-indeed, when these flutes are sold a supply of this rice paper is given with the instruments. Many of our municipal corporations, and also the Colleges at Oxford and Cambridge, possessed sets of Recorders, as indeed they did of cornets and viols, no doubt played for the gratification of their members. I believe the Corporation of Chester still retain an ancient set of four Recorders in their chest. I suppose the term the beaked-Alute, flute-à-bec, was applied at

100 The attempt to explain the origin of the nose flute in the way alluded to by Mr. Southgate is bronght forward by Dr. Tylor, the Oxford Professor of Anthropology, in a paper already mentioned (note 6, p. 150), on "The Asiatic Relations of Polynesian Culture." I believe, however, that Dr. Tylor is by no means convinced that the explanation can be relied on as the true solution of this curious problem. ". . . it is hard to imagine," he writes, "that any flute-player should find his nostrils to have any musical advantage over his mouth. In India, however, where the vansi or pungi have long been filled with the nostrils by snake charmers, performers at the Festival of Nila-paja, \&c., a reason for this practice is currently given which may be the true explanation of its origin. A highcaste Hindu will not touch with his mouth a pipe or flute which has touched the mouth of a lower caste man who made or may have used it, but it does not defile him to blow it with the nostril. This explanation (see Engel, 'Music of Ancient Nations,' p. 59) is stated to me as unquestionable, in answer to an enquiry made of $\mathrm{Dr}$. Sourindro Mohun Tagore, of Calcutta, the best authority on Hindu music. If it be accepted as the real explanation, we may think it probable that the nose flute, thus introduced for ceremonial reasons, followed the course of Hindu colonisation and influence, so as to become established for ordinary musical purposes in islands of the Pacific where its ceremonial origin was unknown."

Engel refers to the subject not only in the work appealed to by Dr. Tylor, but in his " Musical Instruments in the South Kensington Museum," p. $166 .-C$. W. 
